\title{
Effects of Lithium and Carbamazepine on Thyroid Hormone Metabolism in Rat Brain
}

\author{
Andreas Baumgartner, M.D., Graziano Pinna, Ph.D., Luis Hiedra, Ursula Gaio, Carsten Hessenius, \\ Angel Campos-Barros, Ph.D., Murat Eravci, Hans Prengel, Rudy Thoma, Ph.D., \\ and Harald Meinhold, Ph.D.
}

The effects of lithium ( $L I)$ and carbamazepine (CBM) on thyroid hormone metabolism were investigated in 11 regions of the brain and three peripheral tissues in rats decapitated at three different times of day (4:00 A.M., 1:00 P.M., and 8:00 P.M.). Interest was focused on the changes in the two enzymes that catalyze: (1) the 5 'deiodination of $T_{4}$ to the biologically active $T_{3}$, i.e., type II 5 'deiodinase $\left(5^{\prime} \mathrm{D}\right.$ II) and (2) the 5 (or inner-ring) deiodination of $T_{3}$ to the biologically inactive 3'3-T $T_{2}$, i.e., type III 5 deiodinase ( $5 D$ III). A 14-day treatment with both LI and CBM induced significant reductions in $5 D$-III activity. However, $5^{\prime} D-I I$ activity was elevated by CBM and reduced by LI, both administered in concentrations leading to serum levels comparable with those seen in the prophylactic treatment of affective disorders. The effects were dose dependent, varied according to the region of the brain under investigation, and strongly depended on the time of death within the 24-hour rhythm. The consequences of these complex effects of LI and $C B M$ on deiodinase activities for thyroid hormone function in the CNS and also their possible involvement in the mechanisms underlying the mood-stabilizing effects of both $L I$ and CBM remain to be investigated. (c) 1997 American College of Neuropsychopharmacology [Neuropsychopharmacology 16:25-41, 1997]
KEY WORDS: Lithium, Carbamazepine; Thyroid hormones; Deiodinases; Rat brain

Lithium (LI) and carbamazepine (CBM) are the most important drugs used for prophylaxis in patients with major affective disorder. Although many thousands of studies have been published on the clinical use and biochemical effects of both drugs, the mechanisms underlying their mood-stabilizing effects are as yet unknown (for reviews see Bunney and Garland-Bunney 1987; Jope and Williams 1994; Manji and Lenox 1994; Post 1987; Wood and Goodwin 1987).

From the Department of Nuclear Medicine (Radiochemistry) (AB, GP, LH, UG, CH, AC-B, ME, HP, HM), Universitätsklinikum Benjamin Franklin, Free University of Berlin and Formula Berlin GmbH (RT), Berlin, Germany.

Address correspondence to: Andreas Baumgartner, M.D., Department of Nuclear Medicine (Radiochemistry), Klinikum Benjamin-Franklin, Hindenburgdamm 30, D-12200 Berlin.

Received November 21, 1995; revised April 28, 1996; accepted May 13, 1996.
The most relevant hypotheses on the mechanisms of action of lithium focus on the inhibition of myoinositol1-phosphatase (Kendall and Whitworth 1990; Atack et al. 1993; for reviews, see Gani et al. 1993; Jope and Williams 1994). Further hypotheses concentrate on the lithium-induced inhibition of agonist-stimulated adenylate cyclase-mediated cAMP formation (Masana et al. 1991; Mørk and Geisler 1989). Yet another interesting hypothesis posits that the psychotropic properties of lithium may be due to its effects on G-protein function (Avissar et al. 1988; Avissar and Schreiber 1989, 1990; Carli et al. 1994; Newman et al. 1991). However, the validity of all these hypotheses and many others is still a matter of debate (Dixon et al. 1992; Ellis and Lenox 1991; Honchar et al. 1989; Jope et al. 1992; Mørk and Geisler 1989). Furthermore, common biochemical effects of both lithium and carbarmazepine have only very rarely been reported to date (for reviews, see Post 1987; Calabrese et al. 1994; Post and Weiss 1994).

It has also been known for more than 20 years that both LI and CBM may affect the peripheral production 
and serum concentrations of thyroid hormones (for reviews, see Kushner and Wartofsky 1988; Herman et al. 1991). Recently, several lines of evidence have emerged which suggest that both drugs may also have specific effects on intracellular thyroid hormone metabolism and that these effects may be related to their mood-stabilizing properties. On a clinical level, Roy-Byrne et al. (1984) reported that the serum concentrations of thyroxine $\left(\mathrm{T}_{4}\right)$ and free $\mathrm{T}_{4}\left(\mathrm{fT}_{4}\right)$ were lower in patients with affective disorders who responded to CBM treatment than in nonresponders. Hatterer et al. (1988) and we ourselves (Baumgartner et al. 1995) found higher serum concentrations of triiodothyronine $\left(\mathrm{T}_{3}\right)$ in patients with a favorable response to LI prophylaxis than in nonresponders to LI. Recently, Schöpf and Lemarchand (1994) reported higher levels of free $T_{3}$ in therapy-resistant depressed patients responding to lithium augmentation than in nonresponders.

In basic research, an interaction of LI with the effects of thyroid hormones in the central nervous system (CNS) has also been reported (e.g., Rastogi and Singhal 1977). Additionally, in vitro effects of LI on intracellular thyroid hormone metabolism in rat liver (Männistö 1974) and also in mouse neuroblastoma and GH3 cell lines (St. Germain 1987) have been reported. Bolaris et al. (1995) recently found an increase in nuclear binding of $T_{3}$ in cerebral hemispheres of rats treated either acutely or for 1 week with $5 \mathrm{~mol} / \mathrm{L} / \mathrm{kg}$ LI. In preliminary studies, we investigated the effects of LI and CBM on intracellular thyroid hormone metabolism, i.e., their actions on the three deiodinase enzymes in the rat CNS. This issue would seem to be particularly interesting in as far as the metabolism of $\mathrm{T}_{4}$ in the CNS (of the rat) seems to be subject to a highly specific regulation mechanism that differs substantially from that described in peripheral tissues such as the liver or kidney. In brief, in peripheral tissues most of the active iodothyronine compound $\left(\mathrm{T}_{3}\right)$ is taken up from the blood directly, whereas the $\mathrm{T}_{3}$ supply of the brain depends almost completely on the cellular uptake and intracellular deiodination of $\mathrm{T}_{4}$ (e.g., Crantz et al. 1982). This implies that the supply of $\mathrm{T}_{4}$ and intracellular deiodination are essential for $T_{3}$ function in the CNS. Furthermore, the mechanisms of deiodination in the CNS are also very different from those described in peripheral tissues. In the liver or kidney only one deiodinase isoenzyme, known as type I iodothyronine $5^{\prime}$-deiodinase (5'-D-I) catalyzes the deiodination of all iodothyronines (e.g., $\mathrm{T}_{4}$ to $T_{3}$ or $\mathrm{rT}_{3}, \mathrm{~T}_{3}$ to the different $\mathrm{T}_{2}$ compounds, etc.). In the rat CNS, however, two other deiodinases have been identified. Type II iodothyronine $5^{\prime}$-deiodinase ( $5^{\prime} \mathrm{D}$-II) is a selective outer-ring deiodinase that catalyzes deiodination of $T_{4}$ to $T_{3}$ and of $r T_{3}$ to $3,3^{\prime} T_{2}$. Type III iodothyronine 5-deiodinase (5D-III) catalyzes inner-ring deiodination, thereby metabolizing $T_{4}$ to $\mathrm{rT}_{3}$, and $T_{3}$ to the inactive compound $3,3^{\prime} \mathrm{T}_{2}$ (see Visser et al. 1982; review in Köhrle et al. 1991). In recent studies we found that the antidepressants desipramine (DMI) and fluoxetine and also 24-hour sleep deprivation all enhance the activities of 5'D-II in various regions of rat brain, thereby enhancing CNS concentrations of $\mathrm{T}_{3}$ (Baumgartner et al. 1994a; Campos-Barros et al 1993, 1994, 1995; CamposBarros and Baumgartner 1994). In two preliminary studies we also found that 14-day treatment with LI and CBM enhanced the activity of $5^{\prime} \mathrm{D}$-II and reduced that of 5D-III in the rat frontal cortex and hippocampus, respectively (Baumgartner et al. 1994b, 1994c). These effects were strongly dependent upon the time of day at which the rats were killed. In the present study we therefore set out to investigate the effects of LI and CBM on thyroid hormone metabolism in the rat CNS more thoroughly. We looked at the effects of different doses of the two drugs on deiodinase activity in 11 regions of the CNS and three peripheral tissues after both acute and subchronic administration in rats decapitated at three different times of day. The results have not previously been published, aside from those obtained on subchronic treatment with $\mathrm{LI}$ and CBM respectively in one brain region each, which have been presented in two brief reports (Baumgartner et al. 1994b, 1994c, see above).

\section{MATERIALS AND METHODS}

\section{Materials}

Thyroxine $\left(\mathrm{T}_{4}\right), 3,3^{\prime}, 5^{\prime}$-triiodothyronine $\left(\mathrm{rT}_{3}\right), 3,5,3^{\prime}$-triiodothyronine $\left(\mathrm{T}_{3}\right), 3,5$-diiodothyronine $\left(3,5-\mathrm{T}_{2}\right)$, and $3,3^{\prime}$-diiodothyronine $\left(3,3^{\prime}-\mathrm{T}_{2}\right)$ of the highest available purity were obtained from Henning Berlin $\mathrm{GmbH}$ (Berlin, Germany). $\left[5^{\prime}-{ }^{125} \mathrm{I}\right]-\mathrm{T}_{4},\left[5^{\prime}-{ }^{125} \mathrm{I}\right]-\mathrm{rT}_{3}$, and $\left[3^{\prime}-{ }^{125} \mathrm{I}\right]-\mathrm{T}_{3}$ were prepared for iodothyronine deiodinase assays and radioimmunoassays by radio iodination of $T_{3}, 3,3^{\prime}-T_{2}$ and 3,5- $\mathrm{T}_{2}$ respectively, as described by Meinhold (1986). The tracers with specific radio activities of 50 to 75 $\mathrm{MBq} / \mathrm{nmol}$ were repurified immediately before use with disposable Sep-Pak $\mathrm{C}_{18}$ cartridges (Waters Associates, Milford, MA), yielding a purity $>99 \%$ with ${ }^{125} \mathrm{I}$ - as the only contaminant (Mender et al. 1988). Inner-ring labeled $\left[5^{-125} \mathrm{I}\right]-\mathrm{T}_{3}$ (specific radioactivity $1.0-1.5 \mathrm{MBq} / \mathrm{nmol}$ ) was produced by R. Thoma (Formula Berlin GmbH). Dithiothreitol (DTT) was purchased from Boehringer Mannheim $\mathrm{GmbH}$ (Mannheim, Germany); 6-n-propyl-2-thiouracil (PTU) was from Sigma Chemical Co. (St. Louis, MO). All other chemicals were of reagent grade. Pellets containing $0.15 \%, 0.25 \%$, or $0.3 \% \mathrm{LI}$, i.e., $1.5 \mathrm{~g}, 2.5 \mathrm{~g}$, and $3 \mathrm{~g}$ $\mathrm{LI} / \mathrm{kg}$ pellet feed, were purchased from Altromin. LiCl was purchased from Sigma Chemicals, and CBM was donated by CIBA Geigy (Basle). Pellets containing $0.3 \%$ or $0.4 \% \mathrm{CBM}$ ( $3 \mathrm{~g}$ or $4 \mathrm{~g} \mathrm{CBM} / \mathrm{kg}$ pellet feed) and a LIand CBM-free control diet were also obtained from Altromin. 


\section{Animal Treatments and Tissue Sampling}

Adult male, euthyroid Sprague-Dawley rats (Tierversuchsanstalt, Hanover) weighing about $250 \mathrm{~g}$ were used throughout. They were housed in pairs with a 12-hour light-dark cycle (6:00 A.M. to 6:00 P.M.). All rats had free access to food and water. In the cages of the rats receiving LI, a second bottle of fluid containing $0.9 \% \mathrm{NaCl}$ was installed. After allowing an adjustment period of at least 1 week in the new environment, the pharmacological studies were initiated. The details of the designs of all investigations conducted are given in Table 1 . We first examined the effects of a $0.25 \%$ LI diet, given for 14 days, on deiodinase activity in different brain regions in rats decapitated during the day, i.e., as is conventional in psychopharmacological studies, at 1:00 P.M. As we observed only few effects of LI on deiodinase activity, and these were also difficult to interpret, we raised the dose slightly to $0.3 \%$ and killed the rats at 4:00 A.M. and 8:00 P.M. (group 2a). A further group of rats received a
$0.3 \%$ CBM diet in the same design (group $2 b$ ). In these designs we found convincing effects of the two drugs on deiodinase activity. However, the serum levels of LI (but not those of CBM) were in the toxic range in some of the animals. We therefore further investigated the effects of a $0.15 \%$ LI diet on deiodinase activity (group $3 a$ ). As the effects of the $0.3 \%$ lithium diet on deiodinase activities were more pronounced at 8:00 P.M. than at 4:00 A.M., the effects of the $0.15 \%$ lithium diet were studied at 8:00 P.M. only.

When the rats were killed 12 or 24 hours after a single IP administration of CBM (in a $2 \%$ Tween 80 suspension), we found effects on deiodinase activity which were the reverse of those seen after 14-day treatment (group $6 \mathrm{c}$ ). We therefore finally investigated the effects of CBM administered in the diet for an intermediate time period, i.e., for 7 days, raising the dose to $0.4 \%$ CBM (group 4a). As rats given a $0.3 \%$ LI-containing diet exhibited a significant weight loss in comparison with

Table 1. Drug Doses, Length of Application, Time of Death and Mean Lithium (LI) and Carbamazepine (CBM) Serum Concentrations in All Experimental Groups

\begin{tabular}{|c|c|c|c|c|c|c|c|c|}
\hline Group & $n$ & $\begin{array}{c}\text { Drug/Mode of } \\
\text { Application }\end{array}$ & Dose & $\begin{array}{c}\text { Time or Length } \\
\text { of } \\
\text { Application } \\
\text { (days) }\end{array}$ & $\begin{array}{c}\text { Time of } \\
\text { Decapitation }\end{array}$ & $\begin{array}{c}\text { Mean Serum } \\
\text { Concentration }^{a}\end{array}$ & Range & $\begin{array}{c}\text { Change of } \\
\text { Body Weight }\end{array}$ \\
\hline $1 \mathrm{a}$ & 8 & LI diet & $0.25 \%$ & $14 \mathrm{~d}$ & 1 P.M. & $1.12 \pm 0.20$ & $0.65-1.33$ & $+17.0 \pm 6.1 \%$ \\
\hline b & 8 & control diet & - & $14 \mathrm{~d}$ & 1 P.M. & - & - & $+22.5 \pm 3.4 \%$ \\
\hline $2 a$ & 8 & LI diet & $0.30 \%$ & $14 \mathrm{~d}$ & 4 A.M. & $1.30 \pm 0.35$ & $0.72-1.59$ & $-20.2 \pm 6.7 \%$ \\
\hline $\mathrm{a}$ & 8 & LI diet & $0.30 \%$ & $14 \mathrm{~d}$ & 8 P.M. & $1.37 \pm 0.31$ & $0.97-1.77$ & $-18.3 \pm 6.5 \%$ \\
\hline $\mathrm{b}$ & 8 & CBM diet & $0.30 \%$ & $14 \mathrm{~d}$ & 4 A.M. & $6.41 \pm 1.50$ & $5.30-8.21$ & $+19.3 \pm 2.5 \%$ \\
\hline$b$ & 8 & CBM diet & $0.30 \%$ & $14 \mathrm{~d}$ & 8 P.M. & $5.78 \pm 1.35$ & $3.01-7.14$ & $+20.2 \pm 2.3 \%$ \\
\hline c & 8 & control diet & - & $14 \mathrm{~d}$ & 4 A.M. & - & - & $+22.4 \pm 2.3 \%$ \\
\hline c & 8 & control diet & - & $14 \mathrm{~d}$ & 8 P.M. & - & - & $+21.3 \pm 3.5 \%$ \\
\hline $3 a$ & 6 & LI diet & $0.15 \%$ & $14 \mathrm{~d}$ & 8 P.M. & $0.72 \pm 0.08$ & $0.58-0.85$ & $+18.3 \pm 3.4 \%$ \\
\hline b & 6 & control diet & - & $14 \mathrm{~d}$ & 8 р... & - & - & $+20.2 \pm 4.5 \%$ \\
\hline $4 a$ & 6 & CBM diet & $0.40 \%$ & $7 \mathrm{~d}$ & 4 A.M. & $5.99 \pm 1.90$ & $5.81-7.90$ & $+8.5 \pm 3.0 \%$ \\
\hline $\mathrm{a}$ & 6 & CBM diet & $0.40 \%$ & $7 \mathrm{~d}$ & 8 P.M. & $5.40 \pm 1.98$ & $2.90-9.01$ & $+7.9 \pm 2.1 \%$ \\
\hline $\mathrm{b}$ & 6 & control diet & - & $7 \mathrm{~d}$ & 4 A.M. & - & - & $+12.4 \pm 2.5 \%$ \\
\hline $\mathrm{b}$ & 6 & control diet & - & $7 \mathrm{~d}$ & 8 P.M. & - & - & $+11.3 \pm 3.5 \%$ \\
\hline $5 a$ & 6 & fasting & - & $14 \mathrm{~d}$ & 4 A.M. & - & - & $-14.2 \pm 4.5 \%$ \\
\hline $\mathrm{a}$ & 6 & fasting & - & $14 \mathrm{~d}$ & 8 P.M. & - & - & $-15.3 \pm 3.9 \%$ \\
\hline $\mathrm{b}$ & 6 & control diet & - & $14 \mathrm{~d}$ & 4 A.M. & - & - & $+28.4 \pm 2.5 \%$ \\
\hline $\mathrm{b}$ & 6 & control diet & - & $14 \mathrm{~d}$ & 8 P.M. & - & - & $+30.3 \pm 3.5 \%$ \\
\hline $6 a$ & 6 & LI IP & $7.5 \mathrm{mmol} / \mathrm{L} / \mathrm{kg}$ & 10 P.M. (12 h) & 10 A.M. & $2.63 \pm 0.18$ & $2.45-2.95$ & - \\
\hline $\mathrm{a}$ & 6 & LI IP & $7.5 \mathrm{mmol} / \mathrm{L} / \mathrm{kg}$ & 10 P.M. $(24$ h) & 10 P.M. & $1.91 \pm 0.13$ & $1.75-2.06$ & - \\
\hline $\mathrm{b}$ & 6 & LI IP & $3.0 \mathrm{mmol} / \mathrm{L} / \mathrm{kg}$ & 10 P.M. (12 h) & 10 A.M. & $0.44 \pm 0.07$ & $0.35-0.55$ & - \\
\hline c & 6 & CBM IP & $40 \mathrm{mg} / \mathrm{kg}$ & 10 P.M. (12 h) & 10 A.M. & ND & 一 & - \\
\hline c & 6 & CBM IP & $40 \mathrm{mg} / \mathrm{kg}$ & 10 P.M. (24 h) & 10 P.M. & ND & - & - \\
\hline $\mathrm{d}$ & 6 & complete fast & $一$ & 10 P.M. (12 h) & 10 A.M. & - & - & - \\
\hline $\mathrm{e}$ & 6 & control IP & $\mathrm{NaCl}$ & 10 P.M. $(12$ h) & 10 A.M. & - & - & - \\
\hline $\mathrm{e}$ & 6 & control IP & $\mathrm{NaCl}$ & 10 P.M. (24 h) & 10 P.M. & 一 & - & - \\
\hline
\end{tabular}

Given in mmol/L for LI and in $\mathrm{mg} / \mathrm{l}$ for CBM.

"Percent change in body weight during treatment with LI or CBM and in control animals. $\mathrm{ND}=$ not detectable 
controls, we also investigated the effect of fasting on deiodinase activities in two further "time groups" of rats (group 5a, 4:00 A.M. and 8:00 P.M.; see Table 1). On days 1 to 5 , these rats received only the amount of feed consumed on the respective days by the rats in group $2 \mathrm{a}$, which had received $0.3 \% \mathrm{LI}$ in their diet. From days 6 to 14, the rats were weighed and their diet adjusted on a daily basis in order to achieve a percentage weight loss comparable with that seen in rats fed on a $0.3 \% \mathrm{LI}$ diet (group 2a).

In the acute treatment groups (groups 6a to 6e) one toxic dose $(7.5 \mathrm{mmol} / \mathrm{L} / \mathrm{kg})$ and one more physiologic dose $(3 \mathrm{mmol} / \mathrm{L} / \mathrm{kg})$ and $40 \mathrm{mg} / \mathrm{kg}$ CBM were injected IP, at 10:00 P.M. in each case. A group of control rats received IP injections of saline. The rats were decapitated either 12 or 24 hours later. As the rats having received the high doses of LI (group 6a) took no feed at all during the night and the following day, we investigated a further group that was given no feed at all for 12 hours (group 6d).

The experiments on groups 1 to 6 were carried out consecutively over a period of more than 2 years.

All rats were decapitated without anesthesia. Various regions of their brains were dissected according to Glowinski and Iversen (1966). The pituitary gland, liver, and kidney were also dissected and all tissues immediately frozen at $-70^{\circ} \mathrm{C}$. Blood samples were taken from the decapitation wound and centrifuged. The serum was stored at $-20^{\circ} \mathrm{C}$.

\section{Iodothyronine Deiodinase Assays}

For measurement of deiodination, tissue samples were individually homogenized on ice in 5 to 6 vol of 0.25 mol/L sucrose, $10 \mathrm{mmol} / \mathrm{L}$ HEPES ( $\mathrm{pH} 7.0$ ) containing $10 \mathrm{mmol} / \mathrm{L}$ DTT and immediately frozen in a dry ice/ acetone bath and stored at $-80^{\circ} \mathrm{C}$ until assay. The measurement of types I and II $5^{\prime}$ deiodinase $\left(5^{\prime} \mathrm{D}-\mathrm{I}\right.$ and $5^{\prime} \mathrm{D}-$ II) and type III 5 deiodinase (5D-III) was based on the release of radioiodide from the ${ }^{125}$ I-labeled substrates (Leonard and Rosenberg 1980).

5'D-I and 5'D-II Assay. 5'D-I and S'D-II activities were determined simultaneously by measuring the release of radioiodide from $100,000 \mathrm{cpm}(\sim 2.5 \mathrm{kBq})\left[5^{\prime}-\right.$ ${ }^{125} \mathrm{IJ}_{-} \mathrm{rT}_{3}$ at $5 \mathrm{nmol} / \mathrm{L} \mathrm{rT}_{3}, 20 \mathrm{mmol} / \mathrm{L} \mathrm{DTT}$, in the presence (for $\left.5^{\prime} \mathrm{D}-\mathrm{II}\right)$ and absence $\left(5^{\prime} \mathrm{D}-\mathrm{I}+5^{\prime} \mathrm{D}\right.$-II) of $5^{\prime} \mathrm{D}$-I inhibiting PTU (Visser et al. 1982). 5'D-II was also determined using $\left[5^{\prime}-125 \mathrm{I}\right]-\mathrm{T}_{4}$ as substrate in the presence of $6 \mathrm{nmol} / \mathrm{L} \mathrm{T}_{4}, 30 \mathrm{mmol} / \mathrm{L} \mathrm{DTT}, 1 \mathrm{mmol} / \mathrm{L} \mathrm{PTU}$, and 1 $\mu \mathrm{mol} / \mathrm{L} \mathrm{T}_{3}$, in order to inhibit the inner ring deiodination of $\mathrm{T}_{4}$ in those tissues containing significant type III deiodinase (5D-III) activity (Visser et al. 1982; Kaplan and Yaskoski 1980).

The measurement was conducted after 45 to 90 minutes (usually $60 \mathrm{~min}$ ) of incubation at $37^{\circ} \mathrm{C}$ with 50 to $100 \mu \mathrm{g}$ of protein from the crude homogenate in $100 \mu \mathrm{l}$ of 0.1 $\mathrm{mmol} / \mathrm{L}$ potassium phosphate buffer ( $\mathrm{pH} 7.0), 1 \mathrm{mmol} / \mathrm{L}$ EDTA. The reaction was started by the addition of the tissue homogenate and stopped adding the $50 \mu$ of icecold $5 \%$ BSA, $10 \mathrm{mmol} / \mathrm{L}$ PTU, followed by $400 \mu \mathrm{l}$ of $10 \%$ ice-cold trichloroacetic acid. After centrifugation of $4000 \mathrm{~g}$ for 30 minutes, the supernatant containing the ${ }^{125} \mathrm{I}^{-}$was further purified by cation exchange chromatography on 1.6-ml Dowex 50 WX 8 columns (mesh 100 to 200) (Serva GmbH and Co., Heidelberg, Germany). The iodide was then eluted with $2 \mathrm{mmol} \times 1 \mathrm{ml} 10 \%$ acetic acid and counted in a gamma counter.

5D-III Assay. For determination of 5D-III (inner-ring deiodinase), 20 to $70 \mu \mathrm{g}$ of protein were incubated in a final volume of $100 \mu \mathrm{l} 0.1 \mathrm{mmol} / \mathrm{L}$ potassium phosphate buffer (pH 7.4), $1 \mathrm{mmol} / \mathrm{L}$ EDTA with approximately $1.2 \mathrm{kBq}(\sim 50,000 \mathrm{cpm})$ inner-ring labeled [5- $\left.{ }^{125} \mathrm{I}\right]-$ $\mathrm{T}_{3}$, at $50 \mathrm{nmol} / \mathrm{L} \mathrm{T}_{3}, 20 \mathrm{nmol} / \mathrm{L} \mathrm{DTT}$, and $1 \mathrm{mmol} / \mathrm{L}$ PTU for 60 minutes at $37^{\circ} \mathrm{C}$. Radioiodide release was measured as described above.

Preliminary experiments established that for each tissue: (1) the reaction rates were constant over time for up to 120 minutes in the presence and absence of PTU; (2) the reaction rates were proportional to protein concentrations in the ranges used (50 to $100 \mu \mathrm{g} /$ tube in the $5^{\prime} \mathrm{D}-\mathrm{I}$ and $5^{\prime} \mathrm{D}-\mathrm{II}$ assays; 20 to $70 \mu \mathrm{g} /$ tube in the $5 \mathrm{D}$-III assay); and (3) after incubation, equal amounts of 3,3'$\mathrm{T}_{2}$ and $\mathrm{I}^{-}$were produced from $\mathrm{rT}_{3}(5, \mathrm{VD} \mathrm{I}+\mathrm{II}$ assay) or from $\mathrm{T}_{3}$ (5D-III assay) in homogenates from each of the different tissues, as determined by reversed phase high performance liquid chromatography (HPLC) (EelkmanRooda et al. 1989) of the incubation extracts. Likewise, it was established that equal amounts of $\mathrm{T}_{3}$ and $\mathrm{I}^{-}$were produced from $\mathrm{T}_{4}$ in the $\mathrm{T}_{4} 5^{\prime} \mathrm{D}-\mathrm{II}$ assay. In all assays, control incubations substituted homogenization buffer for tissue homogenates and the amount of ${ }^{125} \mathrm{I}^{-}$produced in the tissue-free controls (usually $0.3 \%$ to $0.5 \%$ of the total radioactivity added) was then subtracted from the sample results. Because the substrates were randomly labeled with ${ }^{125} \mathrm{I}$ at the equivalent $3^{\prime}$ or $5^{\prime}$ positions of the phenolic ring (for $\mathrm{rT}_{3}$ and $\mathrm{T}_{4}$ ) or at the equivalent 3 or 5 positions of the tyrosyl ring (for innerring labeled $\mathrm{T}_{3}$ ) the labeled iodide release was half that of the degraded iodothyronines. This was accounted for in the analysis of the data. The reaction conditions selected were such that less than $10 \%$ to $15 \%$ of the substrate was consumed by enzymatic deiodination. Each experimental point was determined in triplicate with coefficients of variation of less than $5 \%$. The deiodinase activities of the different experimental groups ( 1 to 6 , see Table 1) were measured over a 2-year period (see above). Intra-assay coefficients of variation were regularly determined by measuring three samples from one homogenate in one assay. Almost all ranged between 
$1 \%$ and $3 \%$ for both 5 D-II and 5D-III activities. When the intra-assay coefficients of variation exceeded $5 \%$, the experiment was repeated.

Inter-assay coefficients of variation could not be calculated for all experiments carried out in the whole 2-year period, as our experience has shown that deiodinase activities decrease after several months in both homogenates and tissue samples, even if they are stored at $-70^{\circ} \mathrm{C}$. We also had the impression that differences in the quality of several of the reagents (e.g., DTT), even when purchased from one and the same supplier, may have been responsible for some of the changes in absolute deiodinase values that became evident over the years. It is therefore not possible to make reliable between-group comparisons of our results on deiodinase activities (groups 1 to 6 , see Table 1). However, within one experimental group all tests on a given brain region were always conducted in one assay and can therefore well be compared with each other. This applies in particular to those groups in which the rats were decapitated at different times of day. Each control group was killed at the same time as the respective drug treatment group. Likewise, the experiments on deiodinase activities were also performed together with those for the respective drug treatment group. Protein was assayed by the method published by Bradford (1976), using reagents from BioRad Laboratories (Richmond, CA) and bovine gamma globulin as standard.

Determinations of the Serum Concentrations of $T_{4}, T_{3}$, and TSH. The serum levels of $T_{4}$ and $T_{3}$ were determined by a slightly modified double-antibody radioimmunoassay as previously described for human serum (Meinhold 1986). For assaying total $T_{4}$ and $T_{3}$ in the rat sera, standards were set up in iodothyronine-free rat serum (Stringer and Wynford-Thomas 1982). The serum levels of TSH were measured by specific RIA developed for the rat, using immunoreactants kindly supplied by the National Institutes of Arthritis, Diabetes \& Digestive and Kidney Diseases of the National Institutes of Health (Bethesda, MD). The serum concentrations of lithium were determined by flame photometry and those of CBM by an enzyme-linked immunoassay, both in the laboratory of the Klinikum-Benjamin-Franklin.

\section{Statistical Analysis}

The data are given as means \pm SD in the text and, for greater clarity, as means \pm SEM in the figures. $p$-values of less than .05 were considered significant. Where appropriate, comparisons of the results of the different groups of rats were performed using ANOVA with the factors "time" (morning vs evening) and "drug" (LI/CBM vs saline). Individual rankings were calculated with the aid of the Newman-Keuls test. Single comparisons were performed by the Mann-Whitney U test.

\section{RESULTS}

\section{Serum Concentrations of $L I$ and CBM}

The serum concentrations of $\mathrm{LI}$ and CBM are shown in Table 1. The serum concentrations of CBM were within the lower "prophylactic" range after 7- and 14-day treatment with a $0.3 \%$ and $0.4 \%$ diet, respectively (groups $2 \mathrm{~b}$ and $4 \mathrm{a}$ ). The serum levels of LI were in the prophylactic range after 14-day administration of a $0.15 \%$ LI-containing diet (group 3a) and at the upper end of the therapeutic range after 14-day administration of $0.25 \%$ LI (group 1a). However, some rats that had received $0.3 \%$ LI diet for 14 days had serum concentrations of LI reaching the toxic range (group 2a). In the interests of greater clarity, this group (2a) will be referred to as the "toxic group."

The serum levels of CBM were not measurable 12 or 24 hours after a single IP injection of $40 \mathrm{mg} / \mathrm{kg}$. The serum concentrations of LI were clearly in the toxic range both 12 and 24 hours after IP administration of the high dose of $7.5 \mathrm{mmol} / \mathrm{L} / \mathrm{kg}$ (group 6a). They were at the lower end of the therapeutic range after a single administration of $3 \mathrm{mmol} / \mathrm{L} / \mathrm{kg} \mathrm{LI}$ (group $6 \mathrm{~b}$ ).

\section{Effects of Subchronic Administration of LI and CBM, Respectively, on Deiodinase Activity}

Group 1. Figure 1 reveals that administration of $0.25 \%$ LI in pellets over a 14-day period significantly inhibited $5^{\prime} \mathrm{D}$-II activity in the hypothalamus and cerebellum. Nonsignificant trends toward an increase in $5^{\prime} \mathrm{D}$-II activity were evident in the parieto-occipital cortex $(p=.06)$ and hippocampus ( $p=.09$ ). 5D-III activity was significantly inhibited by LI in the frontal cortex and hypothalamus ( $p<.01$ in both cases, Figure 1). Administration of $0.25 \%$ LI failed to affect $5^{\prime} \mathrm{D}$-I activity in 11 regions of the brain or in the pituitary (data not shown). However, $5^{\prime} \mathrm{D}-\mathrm{I}$ activity was significantly reduced in both the liver and kidney in the lithium-treated rats $(p=.01)$.

Group 2 (High-Dose LI ("Toxic") Treatment, CBM Treatment). The effects of 14-day treatment with a $0.25 \%$ LI diet on deodinase activity were, at least as regards 5'D-II, not completely consistent.

We therefore tried to clarify the effects of LI by investigating the effects of different doses of LI on deiodinase activity: one higher dose $(0.3 \%$ LI diet) and one lower dose $(0.15 \%$ LI diet), both administered for 14 days. The $0.3 \%$ LI dose resulted in toxic serum concentrations of LI in at least some of the rats (Table 1), whereas the rats having received the $0.15 \%$ LI diet had serum levels of LI well within the "prophylactic range" (Table 1). Both groups were killed during the "active period," as we had previously found that the effects of psychotropic drugs on deiodinase activities may heavily depend on the time of death during the 24-hour 

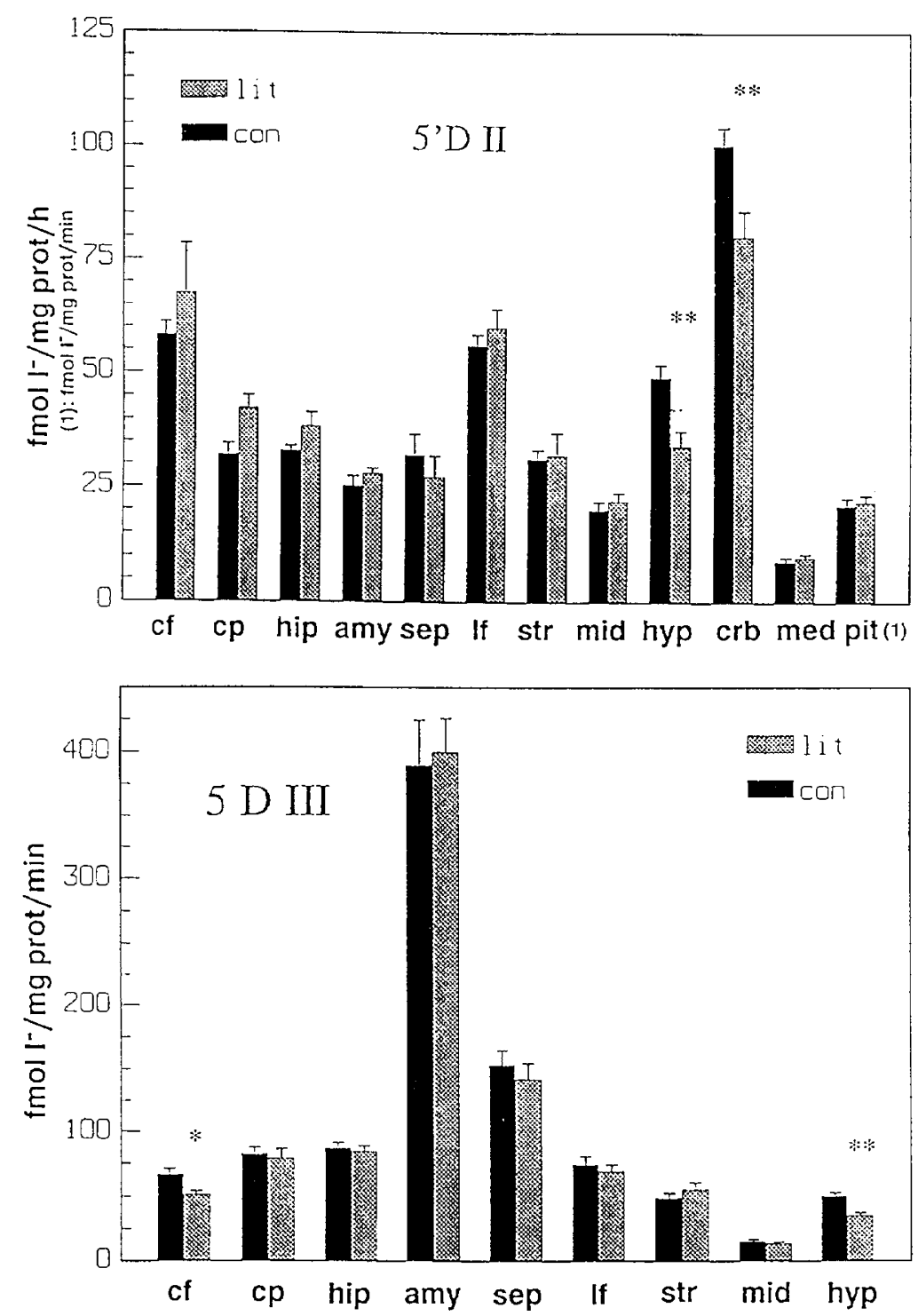

Figure 1. Activities of $5^{\prime} \mathrm{II}$ deiodinase (top) and 5III deiodinase (bottom) in different regions of the brain and pituitary in rats after 14-day administration of a $0.25 \%$ LI diet (time of death 1:00 P.M.; group 1). Abbreviations: $\mathrm{CF}=$ frontal cortex; $\mathrm{CP}=$ parieto-occipital cortex; HIP = hippocampus; $\mathrm{AMY}=$ amygdala; $\mathrm{SEP}=$ septum; $\mathrm{LF}=$ limbic forebrain; STR = striatum; $\mathrm{MID}=$ midbrain; HYP = hypothalamus; $\mathrm{CRB}=$ cerebellum; $\mathrm{MED}=$ medulla $/$ pons; $\mathrm{PIT}=$ pituitary. ${ }^{*}=p<.05,{ }^{* *}=p<.01$, compared with controls. circadian rhythm (Campos-Barros et al. 1994). The "toxic groups" (0.3\% LI diet) were killed at 4:00 A.M. and 8:00 P.M., respectively. The "low-dose group" $(0.15 \%$ LI diet) was sacrificed at 8:00 P.M. only. The effects of $0.3 \%$ LI ("toxic" group") and those of CBM were investigated using the same controls. As we had meanwhile found that the $5^{\prime} \mathrm{D}-\mathrm{I}$ isoenzyme is not present in the human CNS (Campos-Barros et al. 1996) and because the above results failed to show any effect of LI on the activity of this enzyme in any region of the rat brain, in all further experiments 5'D-I was measured in the liver only. Figure 2 shows that the "toxic dose" of LI did not affect the activity of $5^{\prime} \mathrm{D}-\mathrm{II}$ in the rats killed at 4:00 A.M., but significantly enhanced it in 7 out of the 10 brain regions investigated at 8:00 P.M. LI significantly inhibited 5D-III activity in six brain regions at 4:00 A.M. and in five at 8:00 P.M.

As shown in Figure 3, CBM induced a significant increase in the activity of $5{ }^{\prime} \mathrm{D}-\mathrm{II}$ in the hypothalamus $(p<$
$.001)$ and midbrain $(p<.05)$ at 4:00 A.M. and also raised the activity of this enzyme in nine out of the 10 brain regions at 8:00 P.M. After CBM treatment, 5D-III activity was inhibited in the hippocampus at 4:00 A.M. only ( $p=$ $.02)$ At 8:00 P.M. CBM inhibited 5D-III activity in the limbic forebrain $(p=.01)$ and midbrain and septum $(p<.05)$ (Figure 4). Administration of both LI and CBM inhibited 5 'D-I activity in the liver at 4:00 A.M. $(p<.01$ in both cases), but only LI reduced the activity of $5^{\prime} \mathrm{D}$-I at 8:00 P.M. $(p<.01$, data not shown).

Group 3 ("Low-Dose" LI Treatment). The effects of the lower dose of LI $(0.15 \%)$ on deiodinase activities measured at 8:00 P.M. only are shown in Figure 5. LI treatment resulted in a significant decrease in $5^{\prime} \mathrm{D}-\mathrm{II}$ activity in the parieto-occipital cortex, striatum, septum, and hypothalamus. No significant changes were seen in the other five brain regions. 5D-III activity was significantly reduced in the frontal cortex, parieto-occipital 

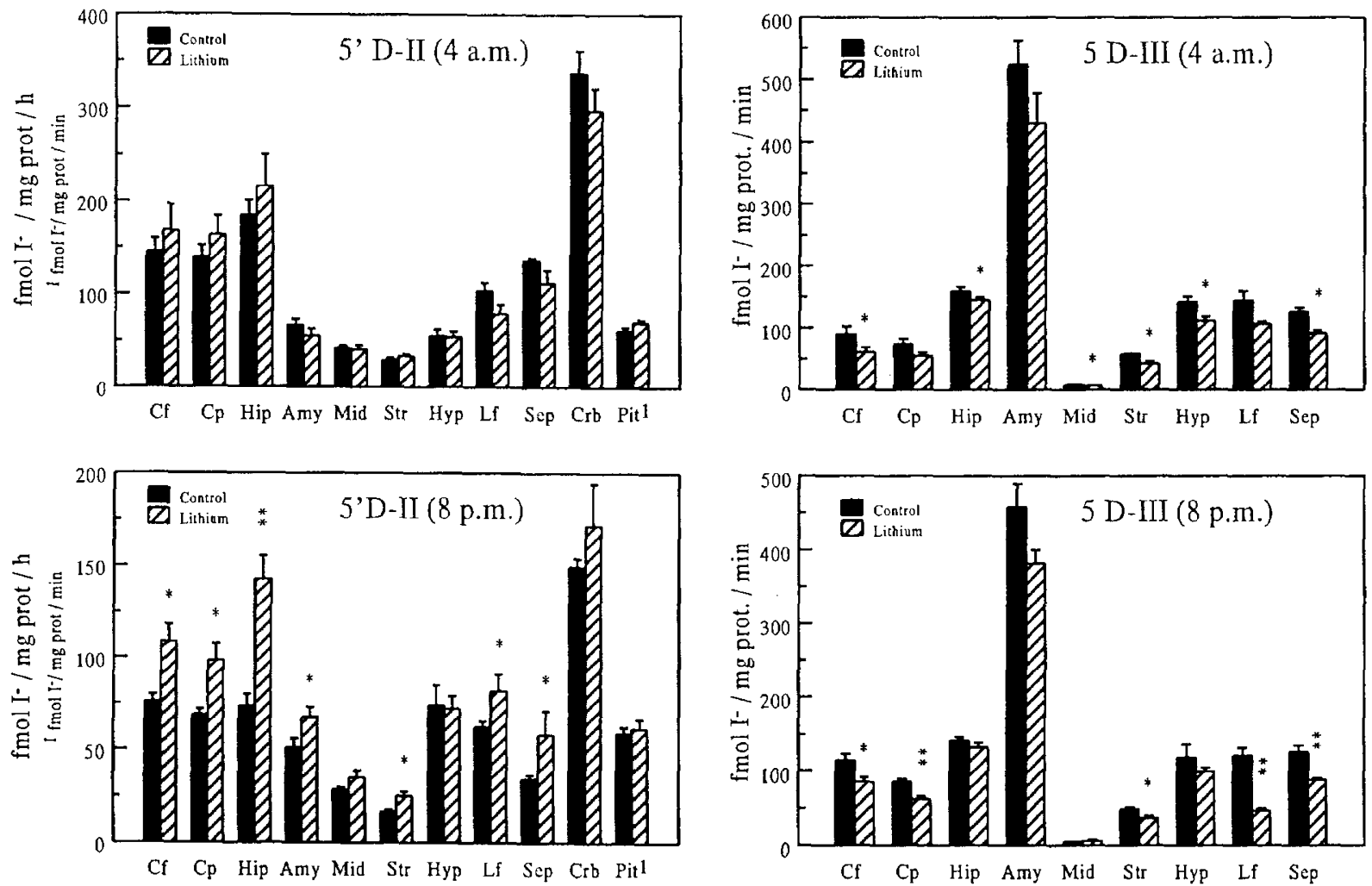

Figure 2. 5'D-II activity (left) and 5D-III activity (right) in rats treated with a $0.3 \%$ LI diet for 14 days and killed at 4:00 A.M. (top) and 8:00 P.M. (bottom) (group 2a). Abbreviations as in Figure 1.

cortex, and limbic forebrain but was enhanced in the hippocampus.

Groups 4 and 5 (Fasting 7-Day CBM Treatment). In the group that fasted for 14 days to an extent causing a weight loss comparable with that of the group that received $0.3 \%$ LI pellets, $5^{\prime} \mathrm{D}$-II was significantly inhibited at 4:00 A.M. in the frontal cortex (Figure 6) and hippocampus. No differences were seen in the rats decapitated at 8:00 P.M. 5D-III was also significantly inhibited in the frontal cortex at 4:00 A.M. $(19.1 \pm 3.5$ vs $26.2 \pm 3.4 \mathrm{fmol}$ $\mathrm{I}-/ \mathrm{mg}$ protein $/ \mathrm{min}$ in the fasting and control rats, respectively), but not at 8:00 P.M. (28.6 \pm 9.2 vs $25.1 \pm 5.3$ fmol I-/mg protein/min, Figure 6). In contrast, 5D-III activity was not inhibited in the hippocampus in the fasting rats at 4:00 A.M. but was reduced at 8:00 P.M. (19.6 \pm 3.4 vs $24.4 \pm 6.2 \mathrm{fmol} \mathrm{I-} / \mathrm{mg}$ protein $/ \mathrm{min}$ at $4: 00$ A.M. and $16.9 \pm 1.4$ vs $20.5 \pm 2.8 \mathrm{fmol} \mathrm{I}-/ \mathrm{mg}$ protein/ $\min$ at 8:00 P.M., $p=.12$ and .02 , respectively). Seven days of treatment with pellets containing the $0.4 \% \mathrm{CBM}$ diet did not significantly affect $5^{\prime} \mathrm{D}$-II or 5D-III activity in the frontal cortex or hippocampus either at 4:00 A.M. or at 8:00 P.M.

Group 6 (Acute Treatment). Twelve hours after a single IP injection of $3 \mathrm{mmol} / \mathrm{L} / \mathrm{kg} \mathrm{LI}$, the activities of 5'D-II and 5D-III were unchanged in the frontal cortex. Twelve and 24 hours after administration of the toxic dose of $7.5 \mathrm{mmol} / \mathrm{L} / \mathrm{kg} \mathrm{LI}$, the levels of $5^{\prime} \mathrm{D}$-II had risen dramatically in both the frontal and parietal occipital cortex, remained unchanged in the hypothalamus and even showed a trend toward a decrease in the pituitary after 12 hours ( $p=.06$, Figure 7). No effect of this toxic dose was seen on 5D-III activity in the frontal cortex or hypothalamus at either measuring time (data not shown). IP administration of $40 \mathrm{mg} / \mathrm{kg}$ CBM failed to have an effect on $5^{\prime} \mathrm{D}$-II activity in the frontal cortex, parieto-occipital cortex, or hypothalamus after 12 hours, but a significant reduction in the activity of this enzyme was found in two of these brain regions in the rats killed after 24 hours (Figure 7). The same treatment regime also failed to affect 5D-III activity in the same brain regions after 12 hours but had significantly enhanced the activity of this enzyme in the frontal cortex and hypothalamus after 24 hours. After 12 hours of total fasting (10:00 P.M. to 10:00 A.M.), 5'D-II activity was significantly elevated in the frontal cortex $\left(125.9 \pm 32.4\right.$ vs $95.2 \pm 9.6 \mathrm{fmol} \mathrm{I}^{-} / \mathrm{mg}$ protein $/ h, p=.02$, for the fasting and control rats, respectively). However, 5D-III activity was not affected by fasting $(13.2 \pm 2.5$ vs $13.8 \pm 2.0 \mathrm{fmol} \mathrm{I}-/ \mathrm{mg}$ protein $/ \mathrm{h}, p=$ $.60)$. No effects were found after 12 and 24 hours of administration of LI $(7 \mathrm{mmol} / \mathrm{L} / \mathrm{kg})$ or CBM $(40 \mathrm{mg} / \mathrm{kg})$ on 5'D-I activity in the liver (data not shown).

The changes in body weight in all groups treated subchronically with LI or CBM and their respective 

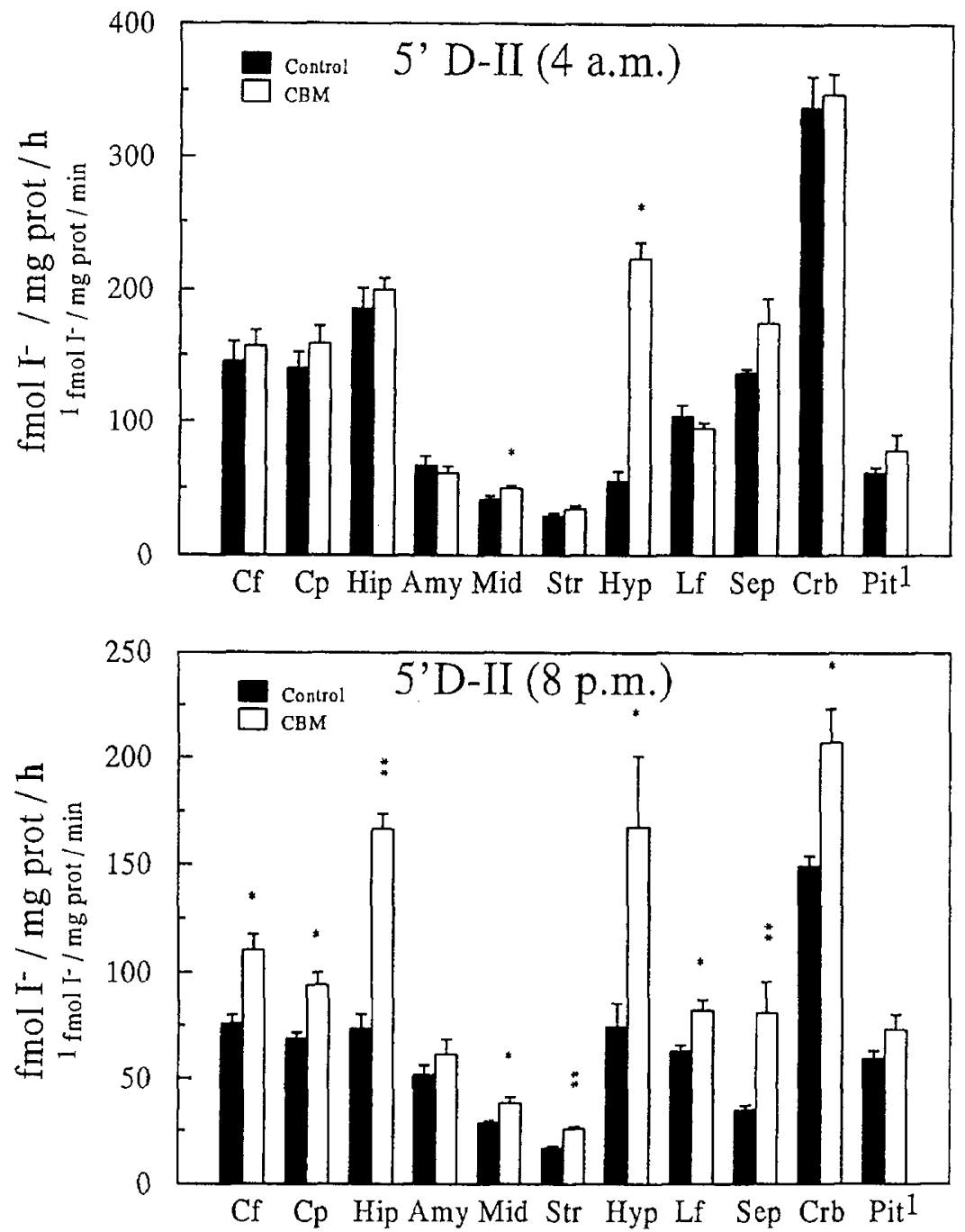

Figure 3. 5'D-II activity in rats treated with a CBM diet $(0.3 \%)$ for 14 days and killed at 4:00 A.M. (top) and 8:00 P.M. (bottom) (group 2b). Abbreviations as in Figure 1. controls are shown in Table 1 (groups 1 to 5). The body weights of the rats having received the $0.25 \%$ and $0.15 \%$ LI diets and the CBM diets, respectively (groups la, $2 b$, $3 a$, and $4 a$ ) did not differ from those found in the rats given the control diet. However, the rats receiving the $0.3 \%$ LI diet for 2 weeks exhibited a considerable weight loss: before death their weight was $31 \%$ lower than in the respective control groups (groups $2 \mathrm{a}$ and $2 \mathrm{c}$ ). On the other hand, rats that had fasted for 14 days also weighed $32 \%$ less than their respective controls prior to decapitation (groups $5 a$ and $5 b$ ).

The results for the serum levels of $\mathrm{T}_{4}, \mathrm{~T}_{3}$, and TSH, which were not measured in all groups, are presented in Table 2. Fourteen days of administration with both the $0.3 \% \mathrm{LI}$ and $0.3 \% \mathrm{CBM}$ diets resulted in lower serum concentrations of $\mathrm{T}_{4}$ and-at 4:00 A.M. at leastalso of $\mathrm{T}_{3}$. Surprisingly, the serum concentrations of $\mathrm{T}_{4}$ and $T_{3}$ were elevated after 14-day administration of the low-dose LI diet $(0.15 \%$; group 3a). The serum levels of both $\mathrm{T}_{3}$ and $\mathrm{T}_{4}$ were dramatically reduced 12 and 24 hours after administration of the toxic dose of LI (7.5 $\mathrm{mmol} / \mathrm{L} / \mathrm{kg}$ ). The concentrations of $\mathrm{T}_{3}$ were also reduced in the rats having fasted completely for 12 hours. The levels of TSH were reduced at 8:00 P.M. after subchronic administration of lithium (group 2a).

\section{DISCUSSION}

Our results show that both $\mathrm{LI}$ and CBM alter thyroid hormone concentrations in the rat CNS. The two drugs seem to have a common effect on 5D-III activity, which was inhibited after 14-day administration of CBM and the "clinically relevant" dose of LI $(0.15 \%)$. However, these effects were rather specific for brain region and time of day. The only exception was seen in the hippocampus, where LI $(0.15 \%)$ stimulated $5 \mathrm{D}-\mathrm{III}$ activity. On the other hand, the two drugs had contrasting effects on 5'D-II activity. Whereas CBM stimulated 5'D-II activity, LI-at least at "clinically relevant" doses-inhibited it (Figures 1, 3, and 4). Surprisingly, 14-day administra- 

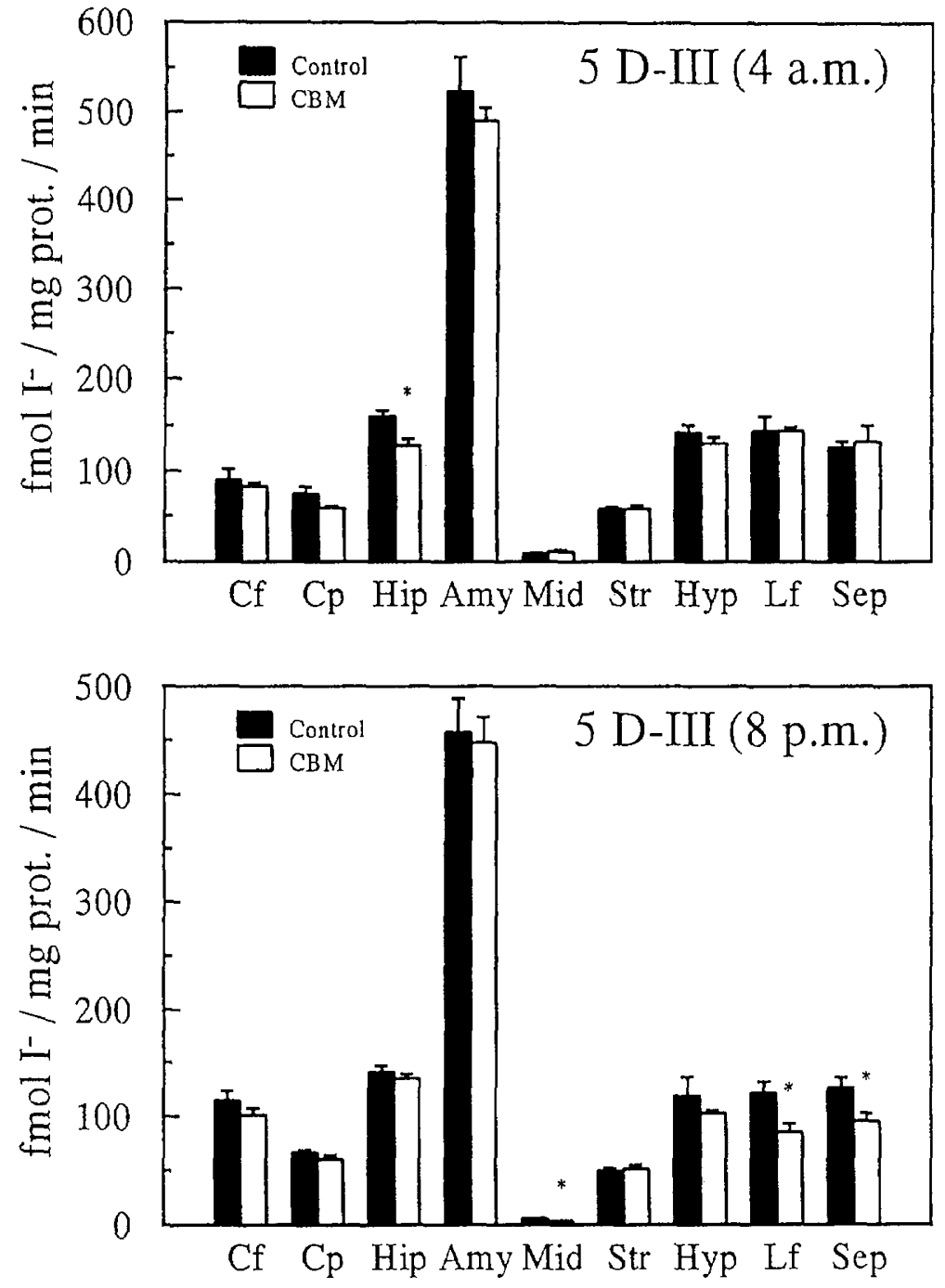

Figure 4. 5D-III activity in rats treated with a CBM diet $(0.3 \%)$ for 14 days and killed at 4:00 A.M. (top) and 8:00 P.M. (bottom) (group 2b). Abbreviations as in Figure 1. tion of the $0.3 \%$ LI diet, which led to toxic levels of LI in roughly half of the rats, enhanced 5 'D-II activity in almost all brain regions, but at 8:00 P.M. only.

As regards the consequences of these changes in deiodinase activities for the production and function of $\mathrm{T}_{3}$, it may be hypothesized that the effects of CBM may result in an increase in $T_{3}$ production. The "net" effect of treatment with "prophylactic" doses of LI on $\mathrm{T}_{3}$ concentrations is however, unclear at present, as LI inhibited 5D-III activity, which should lead to a rise in $\mathrm{T}_{3}$ concentrations and also inhibited $5^{\prime} \mathrm{D}$-II activities, which should reduce the production of $\mathrm{T}_{3}$. The fact that the $5 \mathrm{D}-\mathrm{III}$ activity is about 100 times higher than $5^{\prime} \mathrm{D}-\mathrm{II}$ activity in all brain regions may mean that the "net effect" of LI on $\mathrm{T}_{3}$ concentrations is an increase. However, the same fact also strongly suggests that the two isoenzymes are most likely located in separate cells or subcellular compartments (because otherwise all $\mathrm{T}_{3}$ produced by $5^{\prime} \mathrm{D}-\mathrm{II}$ activity would be instantly degraded by 5D-III and the brain concentrations of $T_{3}$ could not be as high as previously observed [Campos
Barros et al. 1995]). However, both enzymes have only recently been cloned (St. Germain et al. 1994; Davey 1995) and their cellular/subcellular location is yet unknown, whereas their exact role in regulating thyroid hormone function in the CNS is also only incompletely understood. Future studies on these issues may enable us to make more accurate interpretation of the functional significance of the effects of LI on deiodinase activities, which at first glance appear somewhat paradoxical. As regards the literature, to our knowledge as yet only one study has investigated the effects of LI on a "thyroid hormone parameter" in rat CNS. Bolaris et al. (1995) recently reported increased receptor binding of $T_{3}$ to the nucleus but not in the cytoplasm in rat cerebral hemispheres after 1 week of LI treatment. This result would be consistent with an increase in $T_{3}$ production.

In previous studies we had already found that administration of DMI (Campos-Barros and Baumgartner 1994, Campos-Barros et al. 1994, 1995) and sleep deprivation (Campos-Barros et al. 1993), respectively, also enhanced 

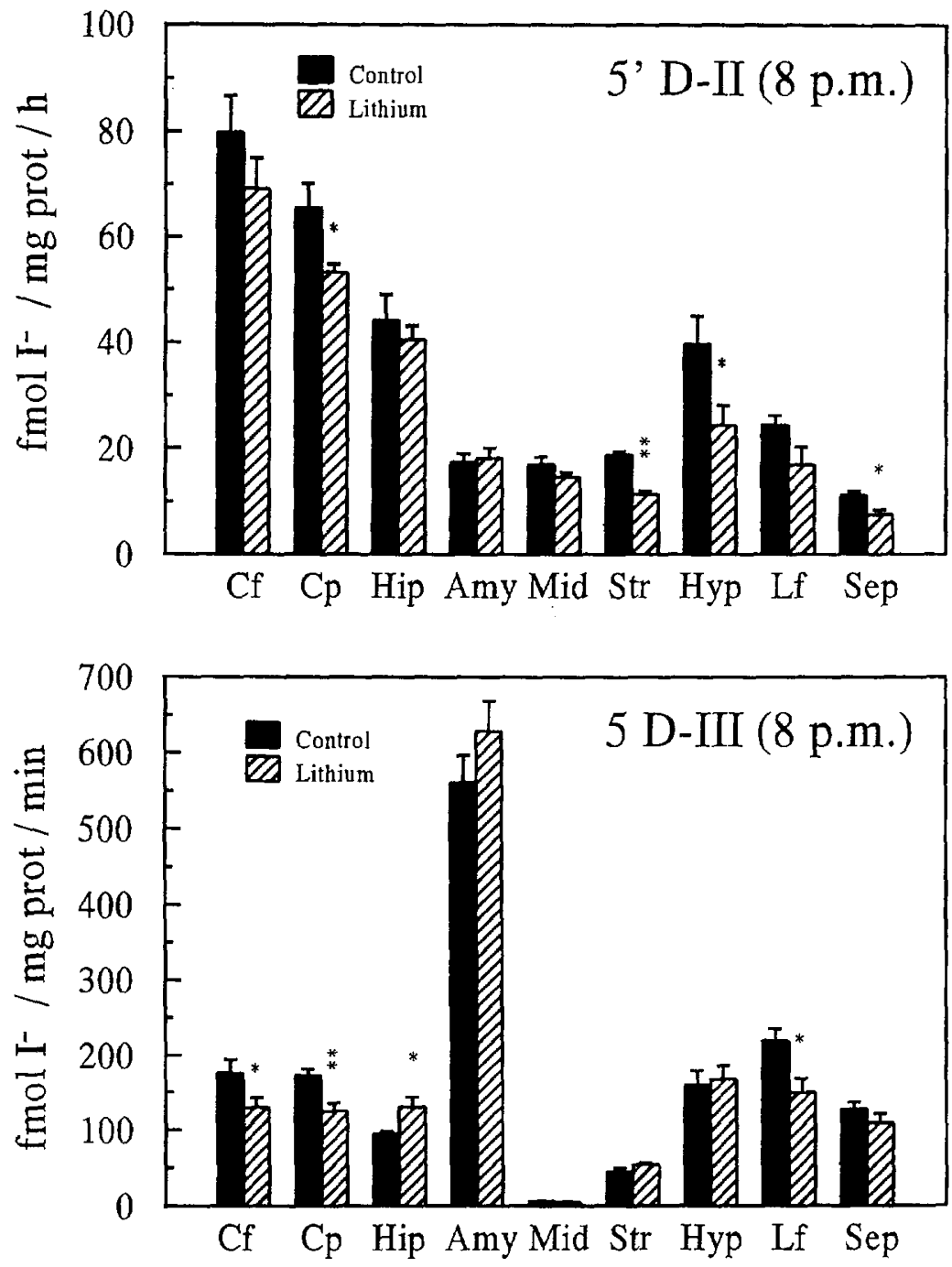

Figure 5. 5'D-II activity (top) and 5-III activity (bottom) in rats having received $0.15 \% \mathrm{LI}$ for 14 days and killed at 8:00 P.M. (group 3a). Abbreviations as in Figure 1. the activity of $5^{\prime} \mathrm{D}-\mathrm{II}$ and did in fact raise the concentrations of $T_{3}$ in rat CNS. Fluoxetine, like LI, enhanced the activity of 5'D-II and inhibited 5D-III activity, but in a more limited number of brain regions (Baumgartner et al. 1994a). It would therefore seem that very different antidepressant treatments such as DMI, fluoxetine, and sleep deprivation all seem to enhance the concentrations of the active thyroid hormone $\mathrm{T}_{3}$ in rat brain. Whether the same also applies to the prophylactic agents CBM and LI remains to be investigated. Based on the data presented in this study it can be hypothesized that the inhibition of 5D-III activity may somehow be involved in the prophylactic action of the two drugs. In contrast, drugs such as desipramine and treatments such as sleep deprivation, which are not prophylactic and may even induce mania, did not affect 5D-III activity but strongly enhanced 5'D-II activity. Studies measuring the effects of all these drugs and treatments, not only on deiodinase activities and $T_{3}$ concentrations but also on functional parameters influenced by $\mathrm{T}_{3}$ in the CNS, are needed for further clarification. From a clinical point of view, as briefly pointed out in the introduction, three studies have all reported that serum levels of $T_{3}$ are higher in responders to prophylactic and/or therapeutic treatment with LI than in nonresponders (Baumgartner et al. 1995; Hatterer et al. 1988, Schöpf and Lemarchand 1994). One study has found lower serum concentrations of $\mathrm{T}_{4}$ in responders to CBM (Roy-Byrne et al. 1984). These results may indicate that interactions of LI and CBM with thyroid hormone metabolism may indeed somehow be involved in their mechanism of action. It is also well known that severe hypothyroidism may mimic all symptoms of affective disorders (for a review, see Hall et al. 1986). Finally, thyroid hormones-both $\mathrm{T}_{3}$ and $\mathrm{T}_{4}$ - have repeatedly been reported to be of value in different treatment regimes in patients with affective disorders (e.g., Bauer and Whybrow 1990; Baumgartner et al. 1994d; Joffe and Singer 1990; Prange et al. 1969).

As shown by the results of basic research, thyroid hormones seem to influence widely varying biochemical functions in the CNS, which are also affected by LI, CBM, and other mood-stabilizing drugs, e.g., beta-recep- 

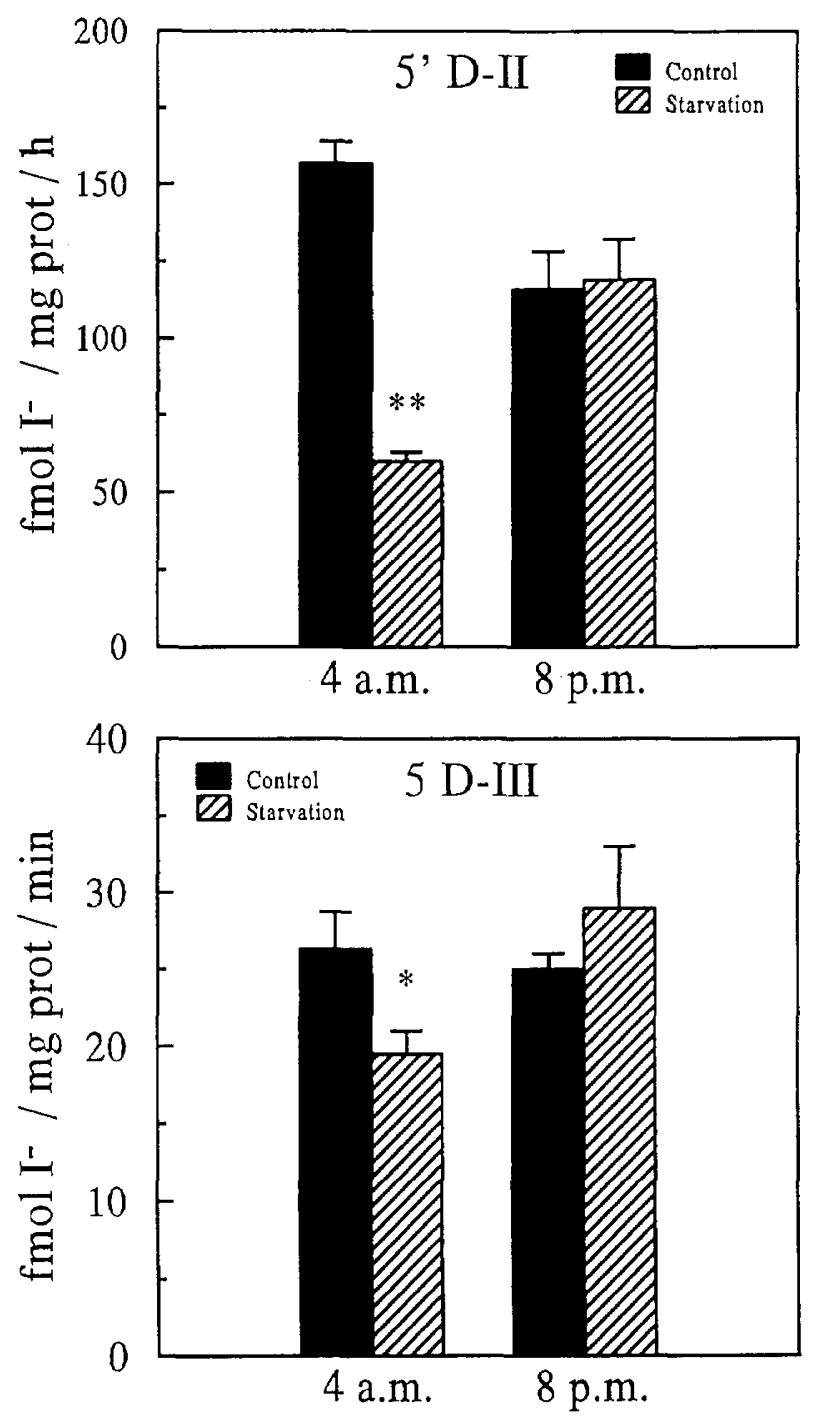

Figure 6. 5 ' D-II activity (top) and 5D-III activity (bottom) in the frontal cortex after 2 weeks of starvation (group $5 \mathrm{a}$ ).

tor density (e.g., Schmidt and Schultz 1985), serotonergic function (e.g., Heal and Smith 1988; Tejani-Butt et al. 1993), dopaminergic function (e.g., Atterwill 1981), GABA uptake and release (e.g., Hashimoto et al. 1991, Mason et al. 1987), adenylate cyclase activity and $G$ protein function (e.g., Michel-Reher et al. 1993; Walz and Howlett 1987), sodium-potassium-ATPase (e.g., Atterwill et al. 1985), fast synaptosomal calcium uptake (e.g., Mason et al. 1990), etc. As it has become increasingly evident in recent years that all our antidepressant and prophylactic therapies affect the functioning of several different neurotransmitter systems, future research strategies should probably focus on the search for common denominators in the mechanisms of action of all these forms of treatment. As already suggested earlier by other authors (e.g., Whybrow and Prange 1981), thyroid hormones may be a reasonable candidate for such a common denominator. However, more systematic research is needed to
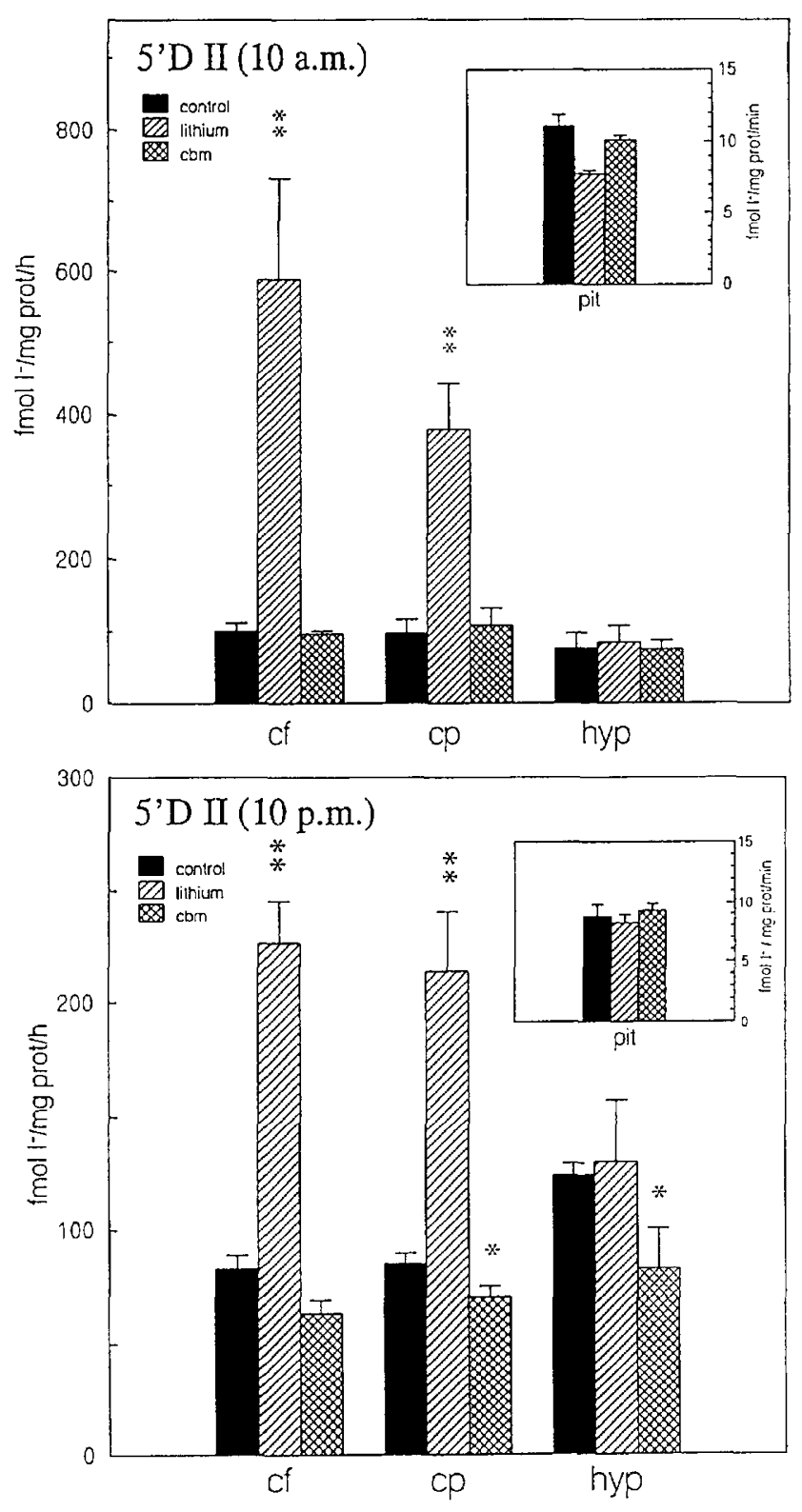

Figure 7. Effects of acute LI $(7.5 \mathrm{mmol} / \mathrm{L} / \mathrm{kg}$, group $6 \mathrm{a})$ or CBM $(40 \mathrm{mg} / \mathrm{kg}$, group $6 \mathrm{c})$ on $5^{\prime} \mathrm{D}$-II activity in different regions of the brain and pituitary at 10:00 A.M. (12 hours after intervention, top) and 10:00 P.M. (24 hours after intervention, bottom). Abbreviations as in Figure 1.

clarify whether thyroid hormones and antidepressants have common effects on relevant CNS functions.

The mechanism of action of the different anticonvulsant drugs is as yet largely unknown (for a review, see MacDonald and McLean 1986, MacDonald 1989). It is therefore somewhat strange that all relevant anticonvulsant drugs, however different their chemical profiles may be, affect serum concentrations of thyroid hormones in patients with convulsive disorder in the same direction. The serum levels of $\mathrm{T}_{4}$ and $\mathrm{fT}_{4}$ usually fall, whereas those of $\mathrm{T}_{3}$ and TSH either remain unchanged or are also reduced by these drugs. These changes have been re- 
Table 2. Thyroxine (T4), Triiodothyronine (T3), and Thyrotropine (TSH) Serum Concentrations in Different Experimental Groups

\begin{tabular}{|c|c|c|c|c|c|c|c|}
\hline Group & & Design & & & $\mathrm{T} 4(\mathrm{nmol} / \mathrm{L})$ & T3 (nmol/L) & TSH (ng/ml) \\
\hline $\begin{array}{r}2 a \\
b \\
c\end{array}$ & $\begin{array}{l}\text { LI } \\
\text { CBM } \\
\text { control }\end{array}$ & $\begin{array}{l}-0.30 \% \\
-0.30 \%\end{array}$ & $\begin{array}{l}-14 d \\
-14 d\end{array}$ & $\begin{array}{l}-4 \text { А.M. } \\
-\quad 4 \text { А.M. } \\
-\quad 4 \text { А.M. }\end{array}$ & $\begin{array}{l}45.8 \pm 13.7^{a} \\
47.7 \pm 5.1^{a} \\
69.5 \pm 11.4\end{array}$ & $\begin{array}{l}1.1 \pm 0.3^{a} \\
1.2 \pm 0.2^{a} \\
1.5 \pm 0.1\end{array}$ & $\begin{array}{l}1.7 \pm 0.4 \\
2.1 \pm 0.7 \\
1.7 \pm 0.7\end{array}$ \\
\hline $\begin{array}{l}a \\
b \\
c\end{array}$ & $\begin{array}{l}\text { LI } \\
\text { CBM } \\
\text { control }\end{array}$ & $\begin{array}{l}-0.30 \% \\
-0.30 \%\end{array}$ & $\begin{array}{l}-14 \mathrm{~d} \\
-14 \mathrm{~d}\end{array}$ & $\begin{array}{l}\text { - } 8 \text { Р.M. } \\
-\quad 8 \text { P.M } \\
-\quad 8 \text { P.M. }\end{array}$ & $\begin{array}{l}55.6 \pm 12.1 \\
45.1 \pm 6.0^{a} \\
67.6 \pm 12.2\end{array}$ & $\begin{array}{l}1.0 \pm 0.3 \\
1.0 \pm 0.1 \\
1.2 \pm 0.1\end{array}$ & $\begin{array}{l}1.5 \pm 0.7^{a} \\
2.2 \pm 0.8 \\
2.5 \pm 0.7\end{array}$ \\
\hline $\begin{array}{r}3 a \\
b\end{array}$ & $\begin{array}{l}\text { LI } \\
\text { control }\end{array}$ & $-0.15 \%$ & $\begin{array}{l}-14 \mathrm{~d} \\
-14 \mathrm{~d}\end{array}$ & $\begin{array}{l}-8 \text { р.м. } \\
-\quad 8 \text { Р.M. }\end{array}$ & $\begin{array}{l}78.5 \pm 12.0^{a} \\
61.4 \pm 8.4\end{array}$ & $\begin{array}{l}1.4 \pm 0.1^{a} \\
1.2 \pm 0.1\end{array}$ & \\
\hline $\begin{array}{r}4 a \\
b\end{array}$ & $\begin{array}{l}\text { CBM } \\
\text { control }\end{array}$ & $-0.40 \%$ & $\begin{array}{l}-7 d \\
-7 d\end{array}$ & $\begin{array}{l}-4 \text { А.M. } \\
-4 \text { А.М. }\end{array}$ & $\begin{array}{l}60.7 \pm 15.9 \\
56.8 \pm 7.1\end{array}$ & $\begin{array}{l}1.2 \pm 0.3 \\
1.2 \pm 0.2\end{array}$ & \\
\hline $\begin{array}{r}4 a \\
b\end{array}$ & $\begin{array}{l}\text { CBM } \\
\text { control }\end{array}$ & $-0.40 \%$ & $\begin{array}{l}-7 \mathrm{~d} \\
-7 \mathrm{~d}\end{array}$ & $\begin{array}{l}\text { - } 8 \text { Р.M. } \\
-8 \text { р.M. }\end{array}$ & $\begin{array}{l}55.6 \pm 6.1 \\
61.8 \pm 7.4\end{array}$ & $\begin{array}{l}1.0 \pm 0.1^{a} \\
1.2 \pm 0.1\end{array}$ & \\
\hline $\begin{array}{r}5 a \\
b\end{array}$ & $\begin{array}{l}\text { fasting } \\
\text { control }\end{array}$ & & $\begin{array}{l}-14 \mathrm{~d} \\
-14 \mathrm{~d}\end{array}$ & $\begin{array}{l}-4 \text { A.M. } \\
-4 \text { A.M. }\end{array}$ & $\begin{array}{l}54.4 \pm 7.4 \\
57.0 \pm 7.4\end{array}$ & $\begin{array}{l}1.3 \pm 0.2 \\
1.2 \pm 0.2\end{array}$ & \\
\hline $\begin{array}{r}5 a \\
b\end{array}$ & $\begin{array}{l}\text { fasting } \\
\text { control }\end{array}$ & & $\begin{array}{l}-14 \mathrm{~d} \\
-14 \mathrm{~d}\end{array}$ & $\begin{array}{l}-8 \text { P.M. } \\
-\quad 8 \text { P.M. }\end{array}$ & $\begin{array}{l}65.5 \pm 5.7 \\
61.4 \pm 8.4\end{array}$ & $\begin{array}{l}1.6 \pm 0.6 \\
1.2 \pm 0.1\end{array}$ & \\
\hline $\begin{array}{r}6 a \\
b \\
c \\
d \\
e\end{array}$ & $\begin{array}{l}\text { LI } \\
\text { LI } \\
\text { CBM } \\
\text { fasting } \\
\text { control }\end{array}$ & $\begin{array}{l}-7.5 \mathrm{mmol} / \mathrm{L} / \mathrm{kg} \\
-3.0 \mathrm{mmol} / \mathrm{L} / \mathrm{kg} \\
-40 \mathrm{mg} / \mathrm{kg}\end{array}$ & $\begin{array}{l}-12 \mathrm{~h} \\
-12 \mathrm{~h} \\
-12 \mathrm{~h} \\
-12 \mathrm{~h}\end{array}$ & $\begin{array}{l}-10 \text { А.м. } \\
-10 \text { А.М. } \\
-10 \text { А.М. } \\
-10 \text { А.М. } \\
-10 \text { А.М. }\end{array}$ & $\begin{array}{l}17.4 \pm 5.9^{a} \\
68.5 \pm 6.5 \\
65.8 \pm 6.5 \\
67.6 \pm 8.9 \\
57.4 \pm 7.9\end{array}$ & $\begin{array}{l}0.3 \pm 0.1^{a} \\
0.7 \pm 0.1 \\
0.8 \pm 0.1 \\
0.5 \pm 0.2 \\
0.8 \pm 0.1\end{array}$ & \\
\hline $\begin{array}{r}6 \mathrm{a} \\
\mathrm{c} \\
\mathrm{e}\end{array}$ & $\begin{array}{l}\text { LI } \\
\text { CBM } \\
\text { control }\end{array}$ & $\begin{array}{l}-7.5 \mathrm{mmol} / \mathrm{L} / \mathrm{kg} \\
-40 \mathrm{mg} / \mathrm{kg}\end{array}$ & $\begin{array}{l}-24 h \\
-24 h\end{array}$ & $\begin{array}{l}-10 \text { р.м. } \\
-10 \text { P.M. } \\
-10 \text { P.M. }\end{array}$ & $\begin{array}{l}27.3 \pm 1.8^{a} \\
58.8 \pm 4.2 \\
57.6 \pm 4.4\end{array}$ & $\begin{array}{l}0.4 \pm 0.03^{a} \\
0.6 \pm 0.06 \\
0.7 \pm 0.1\end{array}$ & \\
\hline
\end{tabular}

${ }^{a} p<.05$

ported after administration of diphenyl hydantoine (DPH) (Cavalieri et al. 1979; Isojärvi et al. 1992), CBM (see Herman et al. 1991 for a review), valproate (Bentsen et al. 1983; Fichsel and Knöpfle 1978), and primidone (Fichsel and Knöpfle 1978). The mechanism(s) underlying these effects are unclear. Furthermore, DPH has been found to inhibit nuclear binding of $\mathrm{T}_{3}$ in the anterior pituitary (Franklyn et al. 1985) and liver (Mann and Surks 1983; Mann et al. 1983; Smith and Surks 1984), acting as a partial $\mathrm{T}_{3}$ agonist. An increase in the uptake of $\mathrm{T}_{4}$ by the erythrocytes (Oppenheimer and Tavernetti 1962) and a decrease in that of $\mathrm{T}_{3}$ in GH3 cell lines (Zemel et al. 1988) have also been observed after administration of DPH. Furthermore, it has been found to induce an increase in 5'D-II deiodinase activity in the cerebellum and "brain," which is comparable to the data reported here for CBM (Schröder-Van der Elst and Van der Heide 1990). Finally, thyroid hormones seem to affect neuronal activity and seizure threshold (Timiras and Woodbury 1956). We therefore feel that more systematic research on the possibility that thyroid hormones may be involved in the mechanism of action of anticonvulsants is warranted.

No in vivo data have as yet been published on the neuronal regulation of the activities of the deiodinases in the
CNS. However, stimulation of $5^{\prime} \mathrm{D}$-II by norepinephrine, isoproterenol, and forskolin have been demonstrated in neonatal rat astrocyte cultures (e.g., Courtin et al. 1988). Activators of protein kinase $C$ have also been shown to enhance 5'D-II activity in astrocytes (Courtin et al. 1989, 1991). Furthermore, there is definite evidence that norepinephrine has a stimulatory effect on 5'D-II activity in both brown adipose tissue and the pineal gland in the rat in vivo. This effect is, in fact, mediated by both $\alpha_{1}$ and $\beta$-adrenergic receptor stimulation (for a review, see Raasmaja, 1990). However, to date no study has investigated the effects of the serotonergic, dopaminergic, GABAergic, or other transmitter systems on the regulation of the activities of the deiodinases. Therefore, further studies on the neuronal regulation of deiodinase isoenzymes are needed before our data can be interpreted.

As a 14-day fast reduces the activity of 5'D-II, which is the reverse of the effects of CBM, its effects on the activity of this enzyme cannot be caused by malnutrition. On the other hand, administration of $0.15 \%$ LI (group 3a) did not induce weight loss in comparison with control rats. It is therefore unlikely that the inhibition of $5^{\prime} \mathrm{D}$-II activity seen after administration of $0.15 \%$ LI was due to weight loss. We found a reduction in 5D-III activity 
in the fasting rats. We cannot therefore exclude the possibility that the inhibition of 5D-III activity found after 14-day administration of high-dosed $(0.3 \%)$ LI may be induced (at least partly) by starvation. This interpretation does not, however, seem likely, for the following reason: 5D-III activity was also significantly inhibited in different brain regions in rats given low-dose $(0.15 \%) \mathrm{LI}$ for 14 days and also in CBM-treated rats (group 2b): however, the weight curves of these two groups did not differ from those found for the controls.

Diminished serum concentrations of thyroid hormones after administration of CBM have also been reported during short-term administration (weeks to months) of this drug to both healthy subjects and patients with affective disorders (e.g., Connell et al. 1984; Herman et al. 1991; Roy-Byrne et al. 1984). This indicates that this drug may have similar effects on thyroid hormone metabolism in both species.

The differing effects of two different dosages of LI on serum levels of thyroid hormones (see Table 2) could be explained by the different effects of the two diets on deiodinase activities. The $0.15 \%$ LI diet reduced $5{ }^{\prime} \mathrm{D}-\mathrm{II}$ and 5D-III activity, thereby inhibiting the intracellular deiodination of both $\mathrm{T}_{4}$ and $\mathrm{T}_{3}$. This could lead to an increase in the mean concentrations of $\mathrm{T}_{4}$ and $\mathrm{T}_{3}$ in the tissue and, secondarily, in the serum. After the $0.3 \%$ LI diet, however, 5'D- II activity was also enhanced, resulting in raised deiodination of $\mathrm{T}_{4}$ and, as a result, a fall in tissue and serum levels of $\mathrm{T}_{4}$.

The mechanisms underlying the dramatic decreases in the serum concentrations of both $\mathrm{T}_{4}$ and $\mathrm{T}_{3}$ seen 12 and 24 hours after IP administration of the toxic dose of $7.5 \mathrm{mmol} / \mathrm{L} / \mathrm{kg} \mathrm{LI}$ are currently unclear. As 5' D-II deiodinase activity was $300 \%$ to $500 \%$ enhanced in cortical areas in this experiment, it seems likely that the decreases in serum levels of $T_{4}$ reflect the dramatic increase in intracellular degradation of $T_{4}$, thus leading to a fall in tissue concentrations of $\mathrm{T}_{4}$ and, secondarily, also in the serum levels of $T_{4}$.

It would also seem relevant that a single IP administration of $3.0 \mathrm{mmol} / \mathrm{L} / \mathrm{kg}$ LI and $40 \mathrm{mg} / \mathrm{kg} \mathrm{CBM}$, respectively, either failed to affect the activity of the deiodinases in the CNS (LI) or even altered them in the reverse direction from the changes seen after 14-day administration (in the case of CBM). Also, our failure to find any changes in deiodinase activity after 7-day administration of CBM in a $0.4 \%$ diet emphasizes the fact that the effects of CBM on deiodinase activity seem to develop slowly over the course of weeks-as is also assumed for its therapeutic action. The highly toxic dose of 7.5 $\mathrm{mmol} / \mathrm{L} / \mathrm{kg}$ induced striking increases in 5'D-II activity in the frontal cortex and parieto-occipital cortex that were evident both 12 and 24 hours after IP administration. However, the activity of this enzyme was not affected in the hypothalamus and was even reduced in the pituitary. This latter result is consistent with those reported by St. Germain (1987), who found a decrease in $5^{\prime} \mathrm{D}$-II activity in cultured pituitary tissue (and in mouse neuroblastoma cell lines) incubated with LI and also in rat pituitary 3 to 24 hours after injection of high doses of lithium. With respect to the dramatic increases in 5'D-II activity in the frontal and parieto-occipital cortex found at 12 and 24 hours after administration of the toxic dose of LI, we are unable to decide whether this is due to a toxic, but specific effect of LI, arising from different stress factors (abdominal pain after IP injection of a large dose), to fasting, or to a combination of all these factors.

The reductions in 5'D-I activity in the liver and kidneys of rats having received LI confirm previous findings by Männistö (1974). The decrease in 5'D-I activity after administration of CBM seems to be a new finding. These effects of the two drugs most likely reflect an adaptational response to the fall in serum levels of thyroid hormones (see Köhrle et al. 1992). In the case of LI an effect of weight loss is also conceivable (Balsam and Ingbar, 1978; Kaplan and Utiger, 1978).

As previously reported for desipramine, both LI and CBM had very different effects on deiodinase activity at different times of the light-dark cycle. For example, if we had investigated the effects of the $0.25 \%$ LI diet on deiodinase activity only in rats killed during their resting period (1:00 P.M., group 1), we would have obtained incomplete and misleading results. At 8:00 P.M. both the lower dose of $0.15 \%$ LI and the higher ("toxic") dose $(0.3 \% \mathrm{LI})$ induced a significant decrease in 5D-III activity in four and five brain regions, respectively, three of which had not been affected at 1:00 P.M. However, effects of the "prophylactic" dose of LI on deiodinase activities were investigated at 8:00 P.M. only. Thus, more studies are needed to gain more insight into the circadian effects of "clinical relevant" doses of LI on deiodinase activities.

Several chronobiological effects of LI have been described in the literature (e.g., Kripke and Whyborney 1980; McEachron et al. 1982; Wilkinson et al. 1987; for a review, see Klemfuss 1992). Theoretically there may be several reasons for these effects: diurnal variations in drug intake and availability, variations in light conditions and activity during the light-dark cycle, a diurnal rhythm in the sensitivity of the CNS to different drugs, etc.

In group 2 the serum concentrations of LI and CBM were almost identical at 4:00 A.M. and 8:00 P.M. Thus, the time-dependent drug effects cannot be explained by diurnal variations in food intake.

We recently found that the activity of the $5^{\prime} \mathrm{D}$-II isoenzyme has a pronounced circadian rhythm in all regions of the rat brain, with increases during the dark phase, peak values between midnight and 4:00 A.M. and decreases in activity levels between 4:00 A.M. and 8:00 A.M. (Campos-Barros et al., submitted). A glance at Figure 2 shows that $5^{\prime} \mathrm{D}$-II activities measured in the control groups at 4:00 A.M. were significantly higher than those 
determined at 8:00 P.M. in all brain regions, but not in the pituitary gland. The possibility cannot therefore be excluded that the changes found in the activities of this isoenzyme at 8:00 P.M. reflect a "phase shift" of the nocturnal peak, rather than a "true" change in the absolute amount of the 24-hour enzyme activity and production of $\mathrm{T}_{3}$. In this case, $\mathrm{CBM}$ would induce a "phase advance" and the $0.15 \%$ LI dose a "phase delay" of the nocturnal peak of 5'D-II activity. More frequent measurement of both deiodinase activities and tissue concentrations of thyroid hormones are needed to clarify this.

However, the 5D-III isoenzyme activity has no diurnal rhythm in any region of the rat brain (Campos-Barros et al., submitted). As can also be seen from Figure 2, the 5DIII activities of the control rats were roughly the same at 4:00 A.M. and 8:00 P.M. in all brain regions. The inhibition of the activity of 5D-III by both drugs would therefore seem to reflect a "true" reduction in $\mathrm{T}_{3}$ degradation per 24-hour cycle. (Note that the differences in baseline 5DIII activities in the controls between, for example, the 1:00 P.M. results of group 1 and the 4:00 A.M. or 8:00 P.M. results in group 2 do not reflect "true" diurnal variations but are exclusively due to the fact that the experiments on the different groups were performed over a period of more than 2 years and the absolute values are therefore no longer directly comparable (see Methods)).

We conclude that in light of these and our previous results (Campos-Barros et al. 1994), future research on the effects of psychopharmacologic drugs should carefully consider the circadian fluctuations in the susceptibility of the brain.

\section{ACKNOWLEDGMENTS}

This study was supported by Deutsche Forschungsgemeinschaft (DFG), Grant Ba932/5-2. The authors would like to thank CIBA Geigy for providing carbamazepine, the laboratory of the Klinikum Benjamin-Franklin for measuring the serum levels of lithium and carbamazepine, and Ines Frege, Alberto Musa, Marco Bachmann, and Stefan Kley for technical assistance.

\section{REFERENCES}

Atack JR, Prior AM, Griffith D, Ragan CI (1993): Characterization of the effects of lithium on phosphatidylinositol (PI) activity in human muscarinic (m1) receptor-transfected CHO cells. Br J Pharmacol 110:809-815

Atterwill CK (1981): Effect of acute and chronic tri-iodothyronine (T3) administration to rats on central 5-HT and dopamin-mediated behavioural responses and related brain biochemistry. Neuropharmacology 20:131-144

Atterwill CK, Atkinson DJ, Bermudez I, Balazs R (1985): Effect of thyroid hormone and serum on the development of $\mathrm{Na}+, \mathrm{K}+$-adenosine triphosphatase and associated ion fluxes in cultures from rat brain. Neuroscience 14:361-373

Avissar S, Schreiber G, Danon A, Belmaker RH (1988): Lithium inhibits adrenergic and cholinergic increases in GTP binding in rat cortex. Nature 331:440-442

Avissar S, Schreiber G (1989): Muscarinic receptor subclassification and G-proteins: Significance for lithium action in affective disorders and for the treatment of the extrapyramidal side effects of neuroleptics. Biol Psychiatry 26:113-130

Avissar S, Schreiber G (1990): Carbamazepine and electroconvulsive shock attenuate $\beta$-adrenoceptor and muscarinic cholinoceptor coupling to $G$ proteins in rat cortex. Eur J Pharmacol 189:89-103

Balsam A, Ingbar SH (1978): The influence of fasting, diabetes, and several pharmacological agents on the pathways of thyroxine metabolism in rat liver. J Clin Invest 21:415-424

Bauer MS, Whybrow PC (1990): Rapid cycling bipolar affective disorder. II. Treatment of refractory rapid cycling with high-dose levothyroxine: A preliminary study. Arch Gen Psychiatry 47:435-440

Baumgartner A, Dubeyko M, Campos-Barros A, Eravci M, Meinhold H (1994a): Subchronic administration of fluoxetine to rats affects triiodothyronine production and deiodination in regions of the cortex and in the limbic forebrain. Brain Res 635:68-74

Baumgartner A, Campos-Barros A, Gaio U, Hessenius C, Frege I, Meinhold H (1994b): Effects of lithium on thyroid hormone metabolism in rat frontal cortex. Biol Psychiatry 36:771-774

Baumgartner A, Campos-Barros A, Gaio U, Hessenius C, Flechner A, Meinhold $H$ (1994c): Carbamazepine affects triiodothyronine production and metabolization in rat hippocampus. Life Sci 54:PL401-407

Baumgartner A, Bauer M, Hellweg R (1994d): Treatment of intractable non-rapid cycling bipolar affective disorder with high-dose thyroxine: An open clinical trial. Neuropsychopharmacology 10:183-189

Baumgartner A, von Stuckrad M, Müller-Oerlinghausen B, Gräf K-J, Kürten I (1995): The hypothalamic-pituitarythyroid axis in patients maintained on lithium prophylaxis for years: High triiodothyronine serum concentrations are correlated to the prophylactic efficacy. J Affective Disord 34:211-218

Bentsen KD, Gram L, Veje A (1983): Serum thyroid hormones and blood folic acid during monotherapy with carbamazepine or valproate. A controlled study. Acta Neurol Scand 67:235-241

Bolaris S, Margarity M, Valcana T (1995): Effects of LiCl on triiodothyronine $\left(\mathrm{T}_{3}\right)$ binding to nuclei from rat cerebral hemispheres. Biol Psychiatry 37:106-111

Bradford MM (1976): A rapid and sensitive method for the quantitation of microgram quantities of protein utilizing the principle of protein-dye binding. Anal Biochem 72:248-254

Bunney WE, Garland-Bunney BL (1987): Mechanism of action of lithium in affective illness: Basic and clinical implications. In Meltzer HY (ed.), Psychopharmacology. New York, Raven Press, pp. 553-565

Calabrese JR, Bowden C, Woyshville MJ (1994): Lithium and the anticonvulsants in the treatment of bipolar disorder. In Bloom FE, Kupfer DJ (eds), Psychopharmacology. The Fourth Generation of Progress. New York, Raven Press, pp 1099-1112

Campos-Barros A, Baumgartner A (1994): Effects of chronic 
desipramine treatment of thyroid hormone concentrations in rat brain: Dependency on drug dose and brain area. Biol Psychiatry 35:214-216

Campos-Barros A, Köhler R, Müller F, Eravci M, Meinhold H, Wesemann W, Baumgartner A (1993): The influence of sleep deprivation on thyroid hormone metabolism in rat frontal cortex. Neurosci Lett 162:145-148

Campos-Barros A, Meinhold H, Stula M, Müller F, Köhler R, Eravci M, Putzien O, Baumgartner A (1994): The influence of desipramine on thyroid hormone metabolism in rat brain. J Pharmacol Exp Ther 268:1143-1152

Campos-Barros A, Meinhold H, Köhler R, Müller F, Eravci M, Baumgartner A (1995): The effects of desipramine on thyroid hormone concentrations in rat brain. NaunynSchmiedeberg's Arch Pharmacol 353:469-474

Campos-Barros A, Höll T, Stoltenburg G, Musa A, Pinna G, Eravci M, Meinhold H, Baumgartner A (1996): Phenolic and tyrosyl ring iodothyronine deiodination and thyroid hormone concentrations in the human central nervous system. J Clin Endocrinol Metab 81:2179-2185

Cameron OG, Smith CB (1980): Comparison of acute and chronic lithium treatment on $3 \mathrm{H}$-norepinephrine uptake by rat brain slices. Psychopharmacology 67:81-85

Carli M, Anand-Srivastava MB, Molina-Holgado E, Dewar KM, Reader TA (1994): Effects of chronic lithium treatments on dopaminergic receptor systems: $G$ proteins as possible targets. Neurochem Int 24:13-22

Cavalieri RR, Gavin LA, Wallace A, Hammond ME, Cruse K (1979): Serum thyroxine, free $T_{4}$, triiodothyronine, and reverse- $\mathrm{T}_{3}$ in diphenylhydantoin-treated patients. Metabolism 28(11):1161-1165

Connell JMC, Rapeport WG, Gordon S, Brodie MJ (1984): Changes in circulating thyroid hormones during shortterm hepatic enzyme induction with carbamazepine. Eur J Clin Pharmacol 26:453-456

Courtin F, Chantoux F, Pierre M, Francon J (1988): Induction of Type II $5^{\prime}$-deiodinase activity cyclic adenosine $3^{\prime}, 5^{\prime}$ monophosphate in cultured rat astroglial cell. Endocrinology 123:1577-1581

Courtin F, Chantoux F, Gavaret J-M, Toru-Delbauffe D, Jacquemin C, Pierre M (1989): Induction of type II5'deiodinase activity in cultured rat astroglial cells by 12-O-tetradecanoylphorbol-12-acetate: Dependence on glucocorticoids. Endocrinology 125:1277-1281

Courtin F, Liva P, Gavaret JM, Toru-Delbauffe D, Pierre M (1991): Induction of 5-deiodinase activity in astroglial cells by 12-O-tetradecanoylphorbol 12-acetate and fibroblast growth factors. J Neurochem 56:1107-1132

Crantz FR, Silva JE, Larsen PR (1982): Analysis of the sources and quantity of 3,5,3'-iodothyronine specifically bound to nuclear receptors in rat cerebral cortex and cerebellum. Endocrinology 110:367-375

Davey JC, Becker KB, Schneider MJ, St. Germain DL, Galton VA (1995): Cloning of a cDNA for the type II iodothyronine deoidinase. J Biol Chem 270:26786-26789

Dixon JF, Lee CH, Los GV, Hokin LE (1992): Lithium enhances accumulation of $[3 \mathrm{H}]$ inositol radioactivity and mass of second messenger inositol 1,4,5-trisphosphate in monkey cerebral cortex slices. J Neurochem 59:2332-2335

Eelkman-Rooda SJ, Otten MH, van Loon MAC, Kaptein E, Visser TJ (1989): Metabolism of triiodothyronine in rat hepatocytes. Endocrinology 125:2187-2192
Ellis J, Lenox RH (1991): Receptor coupling to G proteins: Interactions not affected by lithium. Lithium 2:141-147

Fichsel H, Knöpfle G (1978): Effects of anticonvulsant drugs on thyroid hormones in epileptic children. Epilepsy 19:323-336

Franklyn JA, Davis JRE, Ramsden DB Sheppard MC (1985): Phenytoin and thyroid hormone action. J Endocrinol 104:201-204

Gani D, Downes CP, Batty I, Bramham J (1993): Lithium and myo-inositol homeostatis. Biochem Biophys. Acta 1177:253-269

Glowinski I, Iversen LL (1966): Regional studies of catecholamine metabolism in the rat brain. I. The disposition of $[3 \mathrm{H}]$ dopamine and $[3 \mathrm{H}]$ dopa in various regions of the brain. J Neurochem 13:655-669

Hall RC, Stickney S, Baerrisford TP (1986): Endocrine disease and behaviour. Integ Psychiatry 4:122-133

Hashimoto H, Walker CH, Prange AJ, Mason GA (1991): The effects of thyroid hormones on potassium-stimulated release of $3 \mathrm{H}-\mathrm{GABA}$ by synaptosomes of rat cerebral cortex. Neuropsychopharmacology 5:49-54

Hatterer JA, Kocsis JH, Stokes PE (1988): Thyroid function in patients maintained on lithium. Psychiatry Res 26:249-257

Heal DJ, Smith SL (1988): The effects of acute and repeated administration of T3 to mice on 5-HT1 and 5-HT2 function in the brain and its influence on the actions of repeated electroconvulsive shock. Neuropharmacology 27:12391248

Herman R, Obarzanek E, Mikalauskas KM, Post RM, Jimerson DC (1991): The effects of carbamazepine on resting metabolic rate and thyroid function in depressed patients. Biol Psychiatry 29:779-788

Honchar MP, Ackermann KE, Sherman WR (1989): Chronically administered lithium alters neither myo-inositol monophosphatase activity nor phosphoinositide levels in rat brain. J Neurochem 53:590-594

Isojärvi JIT, Pakarinen AJ, Myllylä VV (1992): Thyroid function with antiepileptic drugs. Epilepsia 33:142-148

Joffe RT, Singer W (1990): A comparison of triiodothyronine and thyroxine in the potentiation of tricyclic antidepressants. Psychiatry Res 32:241-251

Jope RS, Song L, Kolasa K (1992): Inositol trisphosphate, cyclic AMP, and cyclic GMP in rat brain regions after lithium and seizures. Biol Psychiatry 31:505-514

Jope RS, Williams MB (1994): Lithium and brain signal transduction systems. Biochem Pharmacol 47:429-441

Kaplan MM, Utiger RD (1978): Iodothyronine metabolism in rat liver homogenates. J Clin Invest 61:459-471

Kaplan MM, Yaskoski K (1980): A Phenolic and tyrosol ring deiodination of iodothyronines in rat brain homogenates. J Clin Invest 66:551-562

Kendall DA, Whitworth P (1990): Lithium amplifies inhibitions of inositol phospholipid hydrolysis in mammalian brain slices. Br J Pharmacol 100:723-728

Klemfuss H (1992): Rhythms and the pharmacology of lithium. Pharmacol Ther 56:53-78

Köhrle J, Hesch D, Leonard JL (1991): Intracellular pathways of iodothyronine metabolism. In Bravemann LE, Utiger RD (eds), The Thyroid. Philadelphia, Lippincott, pp 144-189

Kripke DF, Whyborney VG (1980): Lithium slows rat circadian activity rhythms. Life Sci 26:1319-1321 
Kushner JP, Wartofsky L (1988): Lithium-thyroid interactions. In Johnson FN (ed), Lithium and the Endocrine System. Basel, München, Karger, pp 74-98

Leonard JL, Rosenberg IN (1980): Iodothyronine 5'-deiodinase from rat kidney: Substrate specificity and the $5^{\prime}$ deiodination of reverse triiodothyronine. Endocrinology 107:1376-1383

MacDonald RL, McLean MJ (1986): Anticonvulsant drugs: Mechanisms of action. Adv Neurol 44:713-736

MacDonald RL (1989): Antiepileptic drug actions. Epilepsia 30 (Suppl. 1): 519-528

Manji HK, Lenox RH (1994): Long-term action of lithium: A role for transcriptional and posttranscriptional factors regulated by protein kinase C. Synapse 16:11-28

Mann DN, Surks MI (1983): 5,5'-Diphenylhydantoin decreases specific 3,5,3'-triiodothyronine $\left(\mathrm{T}_{3}\right)$ binding in rat hepatic nuclear T3 receptors. Endocrinology 112(5):1723-1731

Mann DN, Kumara-Siri MH, Surks MI (1983): Effect of 5,5'diphenylhydantoin on the activities on hepatic cytosol malic enzyme and mitochondrial $\alpha$-glycerophosphate dehydrogenase in athyreotic rats. Endocrinology 112(5):1732-1738

Männistö PT (1974): Effect of lithium on deiodinating activity of various rat tissues in vitro. Acta Endocrinol $76: 260-272$

Masana MI, Bitran JA, Hsiao JK, Mefford IN, Potter WZ (1991): Lithium effects on noradrenergic-linked adenylate cyclase activity in intact rat brain: An in vivo microdialysis study. Brain Res 538:333-336

Mason GA, Walker CH, Prange AJ Jr, Bondy SC (1987): GABA uptake is inhibited by thyroid hormones: Implications for depression. Psychoneuroendocrinology 12:53-59

Mason GA, Walker CH, Prange AJ Jr (1990): Depolarizationdependent $45 \mathrm{Ca}$ uptake by synaptosomes of rat cerebral cortex is enhanced by L-triiodothyronine. Neuropsychopharmacology 3:291-295

McEachron DL, Kripke DF, Hawkins R, Haus E, Pavlinac D, Deftos L (1982): Lithium delays biochemical circadian rhythms in rats. Neuropsychobiology 8:12-29

Meinhold H (1986): Radioimmunoassay of iodothyronines. In Henneman G (ed), Thyroid Hormone Metabolism. New York, Marcel Dekker, pp. 133-186

Mendel CM, Weisiger RA, Cavalieri RR (1988): Uptake of $3,5,3^{\prime}$-triiodothyronine by the perfused rat liver: Return to the free hormone hypothesis. Endocrinology 123:1817-1824

Michel-Reher MB, Gross G, Jasper JR, Bernstein D, Olbricht T, Brodde O-E, Michel MC (1993): Tissue- and subunitspecific regulation of G-protein expression by hypoand hyperthyroidism. Biochem Pharmacol 45:1417-1423

Mørk A, Geisler A (1989): Effects of lithium ex vivo on the GTP-mediated inhibition of calcium-stimulated adenylate cyclase activity in rat brain. Eur J Pharmacol 168:347-354

Newman M, Klein E, Birmaher B, Feinsod M, Belmaker RH (1983): Lithium at therapeutic concentrations inhibits human brain nonadrenaline-sensitive cyclic AMP accumulation. Brain Res 278:380-381

Newman ME, Shapira B, Lerer B (1991): Effects of lithium and desimipramine on second messenger responses in rat hippocampus: Relation to $G$ protein effects. Neuropharmacology 30:1297-1301

Oppenheimer JJ, Tavernetti RR (1962): Studies on the thyroxine-diphenylhydantoin interaction: Effect of 5,5'-diphenylhydantoin on the displacement of L-thyroxine from thyroxine-binding globulin (TBG). Endocrinology 71:496-504

Post RM (1987): Mechanism of action of carbamazepine and related anticonvulsants in affective illness. In Meltzer HY (ed), Psychopharmacology: The Third Generation of Progress. New York, Raven Press, pp 567-576

Post RM, Weiss SRB (1994): The neurobiology of treatmentresistant mood disorders. In Bloom FE, Kupfer DJ (eds), Psychopharmacology. The Fourth Generation of Progress. New York, Raven Press, pp 1155-1170

Prange AJ Jr, Wilson IC, Rabon AM, Lipton MA (1969): Enhancement of imipramine antidepressant activity by thyroid hormone. Am J Psychiatry 126:457-469

Raasmaja A (1990): Alpa1- and -adrenergic receptors in brown adipose tissue and the adrenergic regulation of thyroxine 5'-deiodinase. Acta Physiol Scand 139:7-53

Rastogi RB, Singhal RL (1977): Lithium: Modification of behavioral activity and brain biogenic amines in developing hyperthyroid rats. J Pharmacol Exp Ther 201:92-102

Roy-Byrne PP, Joffe RT, Uhde TW, Post RM (1984): Carbamazepine and thyroid function in affectively ill patients. Arch Gen Psychiary 41:1150-1153

Schmidt BH, Schultz JE (1985): Chronic throxine treatment of rats down-regulates the noradrenergic cyclic AMP generating system in cerebral cortex. J Pharmacol Exp Ther 233:466-472

Schöpf J, Lemarchand T (1994): Lithium addition in endogenous depressions resistant to tricyclic antidepressants or related drugs: relation to the status of the pituitary-thyroid axis. Pharmacopsychiatry 27:198-201

Schöder-Van der Elst JP, Van der Heide D (1990): Effects of 5,5'-diphenylhydantoin on thyroxine and 3,4,3'-triiodothyronine concentrations in several tissues of the rat. Endocrinology 126(1):186-191

Smith PJ, Surks MI (1984): Multiple effects of 5,5'-diphenylhydantoin on the thyroid hormone system. Endocr Rev 5(4):514-524

St. Germain DL (1987): Regulatory effect of lithium on thyroxine metabolism in murine neural and anterior pituitary tissue. Endocrinology 120:1430-1438

St. Germain DL, Schwartzman RA, Croteau W, Kanamori A, Wang Z, Brown DD, Galton VA (1994): A thyroid hormone-regulated gene in Xenopus laevis encodes a type IIi iodothyronine deiodinase. Proc Natl Acad Sci USA 91:7767-7771

Stringer BMJ, Wynford-Thomas D (1982): Importance of maintaining "human" radioimmunoassay kits for use with rat samples. Horm Res 16:392-397

Tejani-Butt SM, Yang J, Kaviani A (1993): Time course of altered thyroid states on $5-\mathrm{HT}_{1 \mathrm{~A}}$ receptors and $5-\mathrm{HT}$ uptake sites in rat brain: An autoradiographic analysis. Neuroendocrinology 57:1011-1018

Timiras PS, Woodbury DM (1956): Effect on thyroid activity on brain function and brain electrolyte distribution in rats. Endocrinology 58:181-192

Visser TJ, Leonard JL, Kaplan MM, Larsen PR (1982): Kinetic 
evidence suggesting two mechanisms for iodothyronine 5 -deiodination in rat cerebral cortex. Proc Natl Acad Sci USA 79:5080-5084

Walz RA, Howlett AC (1987): Thyroid effects on adenosine $3^{\prime}, 5^{\prime}$-monophosphate levels and adenylate cyclase in cultured neuroblastoma cells. Endocrinology 120:1265-1271

Whybrow PC, Prange AJ (1981): A hypothesis of thyroid-catecholamine receptor interaction. Arch Gen Psychiatry 38:106-113

Wilkinson M, Joshi M, Werstiuk ES, Seggie J (1987): Lithium and rhythms of beta-adrenergic ([3H]CGP-12177) binding in intact rat retina, pineal gland, and hypothalamus. Biol Psychiatry 22:1191-1200

Wood AJ, Goodwin GM (1987): A review of the biochemical and neuropharmacological actions of lithium. Psychol Med 17:579-600

Zemel LR, Biezunski DR, Shapiro LE, Surks MI (1988): 5,5'Diphenylhydantoin decreases the entry of 3,5,3'-triiodoL-thyronine but not L-thyroxine in cultured GH-producing cells. Acta Endocrinol 117:392-398 